\title{
Neuropathological Alterations in Alzheimer Disease
}

\author{
Alberto Serrano-Pozo ${ }^{1}$, Matthew P. Frosch ${ }^{1,2}$, Eliezer Masliah ${ }^{3}$, and Bradley T. Hyman ${ }^{1}$ \\ ${ }^{1}$ Alzheimer Research Unit of the MassGeneral Institute for Neurodegenerative Disease, Department of \\ Neurology of the Massachusetts General Hospital, and Harvard Medical School, Charlestown, Massachusetts \\ 02129-4404 \\ ${ }^{2}$ C.S. Kubik Laboratory for Neuropathology, Massachusetts General Hospital, Boston, Massachusetts 02114 \\ ${ }^{3}$ Department of Neuroscience and Department of Pathology, University of California-San Diego School of \\ Medicine, La Jolla, California 92093-0624 \\ Correspondence: bhyman@partners.org
}

The neuropathological hallmarks of Alzheimer disease (AD) include "positive" lesions such as amyloid plaques and cerebral amyloid angiopathy, neurofibrillary tangles, and glial responses, and "negative" lesions such as neuronal and synaptic loss. Despite their inherently cross-sectional nature, postmortem studies have enabled the staging of the progression of both amyloid and tangle pathologies, and, consequently, the development of diagnostic criteria that are now used worldwide. In addition, clinicopathological correlation studies have been crucial to generate hypotheses about the pathophysiology of the disease, by establishing that there is a continuum between "normal" aging and AD dementia, and that the amyloid plaque build-up occurs primarily before the onset of cognitive deficits, while neurofibrillary tangles, neuron loss, and particularly synaptic loss, parallel the progression of cognitive decline. Importantly, these cross-sectional neuropathological data have been largely validated by longitudinal in vivo studies using modern imaging biomarkers such as amyloid PET and volumetric MRI.

$\mathrm{T}^{\mathrm{h}}$ he neuropathological changes of Alzheimer disease (AD) brain include both positive and negative features. Classical positive lesions consist of abundant amyloid plaques and neurofibrillary tangles, neuropil threads, and dystrophic neurites containing hyperphosphorylated tau (see Box 1 for glossary) (Terry et al. 1994, Mandelkow and Mandelkow 1998, Trojanowski and Lee 2000; Iqbal and Grundke-Iqbal 2002; Crews and Masliah 2010), that are accompanied by astrogliosis (Beach et al. 1989; Itagaki et al. 1989), and microglial cell activation (Rogers et al. 1988; Itagaki et al. 1989; Masliah et al. 1991). Congophilic amyloid angiopathy is a frequent concurrent feature. Unique lesions, found primarily in the hippocampal formation, include Hirano bodies and granulovacuolar degeneration. In addition to these positive lesions, characteristic losses of neurons, neuropil, and synaptic elements are core negative features of $\mathrm{AD}$ (Scheff et al. 1990, 2006, 2007; DeKosky and Scheff 1990;

Editors: Dennis J. Selkoe, David M. Holtzman, and Eckhard Mandelkow

Additional Perspectives on The Biology of Alzheimer Disease available at www.perspectivesinmedicine.org

Copyright (C) 2011 Cold Spring Harbor Laboratory Press; all rights reserved; doi: 10.1101/cshperspect.a006189

Cite this article as Cold Spring Harb Perspect Med 2011;1:a006189 
A. Serrano-Pozo et al.

Terry et al. 1991; Masliah et al. 1993b; Scheff and Price 1993, 1994; Gomez-Isla et al. 1996, 1997; Knowles et al. 1999). Each of these lesions has a characteristic distribution, with plaques found throughout the cortical mantle, and tangles primarily in limbic and association cortices (Arnold et al. 1991; Braak and Braak 1991; Thal et al. 2002). The hierarchical pattern of neurofibrillary degeneration among brain regions is so consistent that a staging scheme based on early lesions in the entorhinal/ perirhinal cortex, then hippocampal Ammon subfields, then association cortex, and finally primary neocortex is well accepted as part of the 1997 NIA-Reagan diagnostic criteria (NIA-RI Consensus 1997). Neuronal loss and synapse loss largely parallel tangle formation, although whether tangles are causative of neuronal loss or synaptic loss remains uncertain (Gómez-Isla et al. 1997; Iqbal and GrundkeIqbal 2002; Bussière et al. 2003; Hof et al. 2003; Yoshiyama et al. 2007; Spires-Jones et al. 2008; de Calignon et al. 2009, 2010; Kimura et al. 2010).

\section{BOX 1. Glossary}

Amyloid plaques: extracellular deposits of amyloid $\beta$ abundant in the cortex of AD patients. Amyloid plaques are commonly classified in diffuse and dense-core based on their morphology and positive or negative staining with Thioflavin-S or Congo Red.

Dense-core plaques: fibrillar amyloid deposits with compact core that stains with Thioflavin-S and Congo Red. Dense-core plaques are typically surrounded by dystrophic neurites (neuritic plaques), reactive astrocytes and activated microglial cells, and associated with synaptic loss. A semiquantitative score of neuritic plaques is used for the pathological diagnosis of AD because their presence is generally associated with the presence of cognitive impairment.

Diffuse plaques: amorphous amyloid deposits with ill-defined contours that are Congo Red and Thioflavin S negative. Diffuse plaques are usually nonneuritic and not associated with glial responses or synaptic loss. This plaque type is not considered for the pathological diagnosis of AD because it is a relatively common finding in the brain of cognitively intact elderly people.

Cerebral amyloid angiopathy (CAA): deposits of amyloid $\beta$ in the tunica media of leptomeningeal arteries and cortical capillaries, small arterioles and medium-size arteries, particularly in posterior areas of the brain. Some degree of CAA, usually mild, is present in $\approx 80 \%$ of $A D$ patients. If severe, CAA can weaken the vessel wall and cause life-threatening lobar hemorrhages.

Amyloid $\beta$ : a 40 or 42 amino acid peptide derived from amyloid precursor protein (APP) after its sequential cleavage by $\beta$ - and $\gamma$-secretases. Its physiological role is likely related to the modulation of synaptic activity although still controversial. In AD A $\boldsymbol{\beta}$ accumulates forming intermediate soluble oligomers that are synaptotoxic as well as insoluble $\beta$-sheet pleated amyloid fibrils that are the main constituent of dense-core plaques (mainly A $\boldsymbol{\beta} 42$ ) and cerebral amyloid angiopathy (primarily A $\boldsymbol{\beta} 40$ ).

Neurofibrillary tangles (NFTs): intraneuronal aggregates of hyperphosphorylated and misfolded tau that become extraneuronal ("ghost" tangles) when tangle-bearing neurons die. NFTs have a stereotypical spatiotemporal progression that correlates with the severity of the cognitive decline. In fact, a topographic staging of NFTs (Braak and Braak 1991) is used for the pathological diagnosis of AD.

Neuropil threads: axonal and dendritic segments containing aggregated and hyperphosphorylated tau that invariably accompany neurofibrillary tangles in AD.

Tau: a microtubule-associated protein normally located to the axon, where it physiologically facilitates the axonal transport by binding and stabilizing the mictrotubules. In AD, tau is translocated to the somatodendritc compartment and undergoes hyperphosphorylation, misfolding, and aggregation, giving rise to neurofibrillary tangles and neuropil threads. 
Although all these neuropathological characteristics are useful diagnostic markers, the cognitive impairment in patients with $\mathrm{AD}$ is closely associated with the progressive degeneration of the limbic system (Arnold et al. 1991; Klucken et al. 2003), neocortical regions (Terry et al. 1981), and the basal forebrain (Teipel et al. 2005). This neurodegenerative process is characterized by early damage to the synapses (Masliah and Terry 1993, 1994; Masliah 2000; Crews and Masliah 2010) with retrograde degeneration of the axons and eventual atrophy of the dendritic tree (Coleman and Perry 2002; Higuchi et al. 2002; Grutzendler et al. 2007; Perlson et al. 2010) and perikaryon (Hyman et al. 1986; Lippa et al. 1992). Indeed, the loss of synapses in the neocortex and limbic system is the best correlate of the cognitive impairment in patients with AD (DeKosky and Scheff 1990; Terry et al. 1991; DeKosky et al. 1996).

In addition to the lesions detected by classical histopathological stains, including silver stains for tangles and plaques or immunostaining and quantitative analysis (or quantitative EM) for synaptic alterations, several lines of investigation now support the view that increased levels of soluble amyloid- $\beta_{1-42}(A \beta)$ oligomers, might lead to synaptic damage and neurodegeneration (Lambert et al. 1998; Klein et al. 2001; Klein 2002; Walsh et al. 2002; Walsh and Selkoe 2004; Glabe 2005; Lesne et al. 2006; Townsend et al. 2006; Lacor et al. 2007). In experimental models, it has been shown that transsynaptic delivery of $A \beta$, for example from the entorhinal cortex to the molecular layer of the dentate gyrus, promotes neurodegeneration characterized by synapse loss (Harris et al. 2010a) and alterations to calbindin-positive neurons (Palop et al. 2003). This is accompanied by circuitry dysfunction and aberrant innervation of the hippocampus by NPY-positive fibers among others (Harris et al. 2010b; Palop et al. 2011). The A $\beta$ oligomers secreted by cultured neurons inhibit longterm potentiation (LTP), damage spines and interfere with activity-regulated cytoskeleton associated protein (Arc) distribution (Klein et al. 2001; Walsh and Selkoe 2004; Townsend et al. 2006; Selkoe 2008). Together, these studies indicate that $A \beta$ oligomers ranging in size from 2 to 12 subunits might be responsible for the synaptic damage and memory deficits in AD (Lacor et al. 2007). Similar neurotoxic $\mathrm{A} \beta$ oligomers found in vitro and in APP transgenic models have been also identified in the CSF (Klyubin et al. 2008) and in the brains of patients with AD (Shankar et al. 2008; McDonald et al. 2010; Pham et al. 2010). These studies have shown that $A \beta$ oligomers progressively accumulate in the brains of $\mathrm{AD}$ patients, although their relationship to the severity of the cognitive impairment remains uncertain.

In summary, in recent years, the concept of neurodegeneration in $\mathrm{AD}$ has been expanded from the idea of general neuronal loss and astrogliosis to include earlier alterations such as synaptic and dendritic injury and disturbances in the process of adult neurogenesis (Jin et al. 2004; Li et al. 2008; Crews et al. 2010), circuitry dysfunction, and aberrant innervation. All of these factors are important targets to consider when developing neuroprotective treatments for AD.

\section{MACROSCOPIC FEATURES}

Although the gross visual examination of the $\mathrm{AD}$ brain is not diagnostic, a typical symmetric pattern of cortical atrophy predominantly affecting the medial temporal lobes and relatively sparing the primary motor, sensory, and visual cortices, is considered strongly suggestive of $\mathrm{AD}$ being the condition underlying the patient's dementia. As a result of this pattern of cortical thinning, the lateral ventricules, particularly their temporal horns, can appear prominently dilated (ex vacuo hydrocephalus). This pattern is stereotypic and can be recognized early in the clinical course of the disease by MRI scan (Dickerson et al. 2009, 2011). Cerebrovascular disease, usually in the form of small vessel occlusive disease caused by chronic hypertension and other vascular risk factors, is a condition that frequently accompanies aging in general and also AD in particular. Thus, it is relatively common to find some cortical 
A. Serrano-Pozo et al.

microinfarcts, lacunar infarcts in the basal ganglia, and demyelination of the periventricular white matter. The presence of cortical petechial microbleeds or even evident lobar hemorrhages, particularly in the posterior parietal and occipital lobes, should lead to the suspicion of a concurrent severe cerebral amyloid angiopathy. Unless there is a concomitant Parkinson's disease or dementia with Lewy bodies, the substantia nigra shows a normal coloration; in contrast, the locus coeruleus is affected in the early stages of AD (Braak and Del Tredici 2011).

\section{MICROSCOPIC FEATURES}

\section{Neurofibrillary Tangles \\ Composition}

The neurofibrillary tangles (NFTs) were first described by Alois Alzheimer in his original autopsy case report as intraneuronal filamentous inclusions within the perikaryal region of pyramidal neurons. Ultrastructural studies on AD brain specimens revealed that NFTs are primarily made of paired helical filaments (PHFs), that is, fibrils of $\approx 10 \mathrm{~nm}$ in diameter that form pairs with a helical tridimensional conformation at a regular periodicity of $\approx 65 \mathrm{~nm}$ (Kidd 1963, 1964; Wisniewski et al. 1976). A small proportion of fibrils within the NFTs do not form pairs, but give the appearance of straight filaments without the periodicity of PHFs (Crowther 1991). Occasional hybrid filaments, with a sharp transition between a paired helical segment and a straight segment, have also been described within NFTs (Crowther 1991). Recently, modern high-resolution molecular microscopy techniques have revealed the presence of twisted ribbon-like assemblies of tau fibrils in vitro, thus challenging the PHF concept (Wegmann et al. 2010). Regardless of the morphology of their structural units, the major constituent of NFTs was found to be the microtubule-associated protein tau, which is aberrantly misfolded and abnormally hyperphosphorylated. Invariably accompanying NFTs are the neuropil threads, which are thought to result from the breakdown of dendrites and axons of the tangle-bearing neurons.

\section{Morphological Characteristics}

The NFTs are argyrophilic and can be shown by silver impregnation methods such as the Gallyas technique (Braak and Braak 1991). An alternative method to examine NFTs is their staining with fluorescent dyes such as Thioflavin-S, which recognize the $\beta$-sheet pleated structure of the paired helical filaments (Arnold et al. 1991), or by immunostaining with antitau antibodies (Fig. 1). Three morphological stages have been distinguished: (1) Pre-NFTs or diffuse NFTs are defined by a diffuse, sometimes punctate, tau staining within the cytoplasm of otherwise normal-looking neurons, with well-preserved dendrites and a centered nucleus; (2) Mature or fibrillar intraneuronal NFTs (iNFTs) consist of cytoplasmic filamentous aggregates of tau that displace the nucleus toward the periphery of the soma and often extend to distorted-appearing dendrites and to the proximal segment of the axon; (3) extraneuronal "ghost" NFTs (eNFTs) result from the death of the tangle-bearing neurons and are identifiable by the absence of nucleus and stainable cytoplasm (Su et al. 1993; Braak et al. 1994; Augustinack et al. 2002). Both silver and Thioflavin-S stains, as well as some phosphotau antibodies such as AT8 and PHF1, preferentially identify the iNFTs and the eNFTs (Braak et al. 1994; Augustinack et al. 2002). By contrast, other phosphoepitopes (e.g., pThr153, pSer262, pThr231) and a certain conformational epitope recognized by the antibodies MC1 and Alz50 also recognize pre-NFTs, suggesting that the misfolding of the tau molecule and its phosphorylation in certain sites represent an early step prior to tau aggregation (Carmel et al. 1996; Weaver et al. 2000; Augustinack et al. 2002). Interestingly, the immunoreactivity for a caspase-cleaved form of tau with a faster rate of fibrillization than the full length molecule in vitro colocalize with Alz50 immunoreactivity in pre-NFTs, suggesting that the caspase-mediated cleavage of the carboxy-terminal region of the tau molecule is 


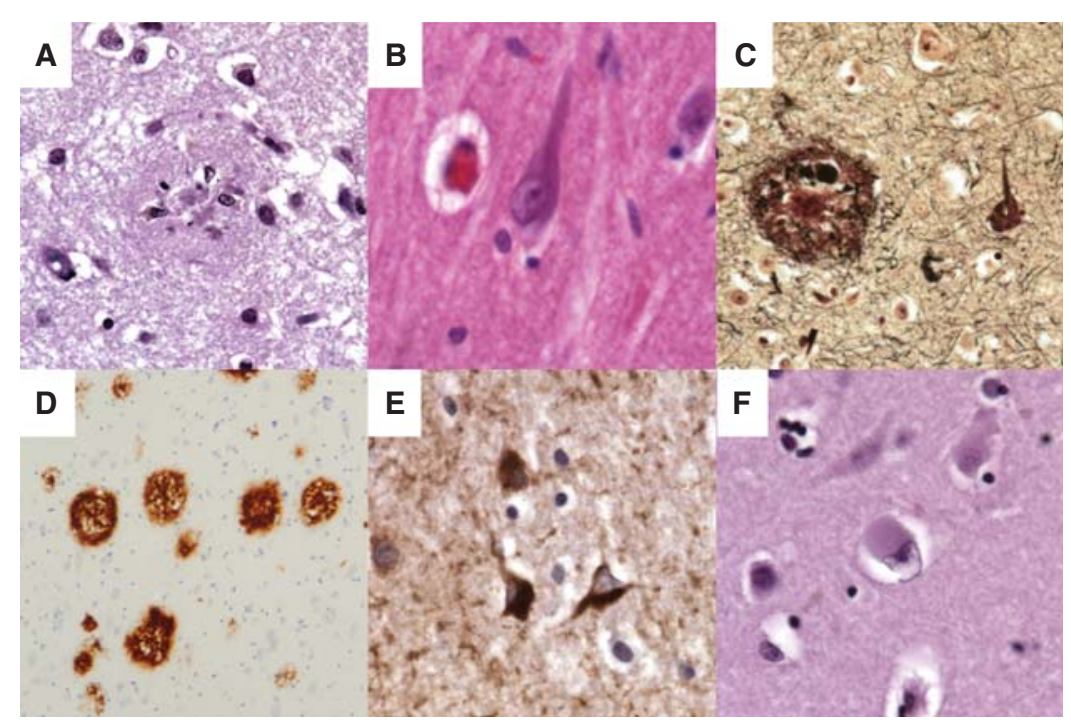

Figure 1. Photomicrographs of the core pathological lesions observed in Alzheimer and Lewy body diseases. (A) Plaque evident on routine H\&E stained section of frontal cortex; $(B)$ tangle in a hippocampal pyramidal neuron on routine $\mathrm{H} \& \mathrm{E}$ stained section; $(C)$ silver stain highlights both a plaque and a tangle; $(D)$ immunohistochemistry against $\mathrm{A} \beta$ highlights plaques; $(E)$ immunohistochemistry against tau highlights tangles; $(F)$ a cortical Lewy body can be seen in a layer V neuron on a routine H\&E stained section of frontal cortex.

also a necessary step prior to further aggregation (Guillozet-Bongaarts et al. 2005).

\section{Topographical Distribution}

The spatiotemporal pattern of progression of NFTs (and neuropil threads in parallel) is rather stereotypical and predictable (Arnold et al. 1991; Braak and Braak 1991; Braak et al. 2006). Briefly, the neurofibrillary degeneration starts in the allocortex of the medial temporal lobe (entorhinal cortex and hippocampus) and spreads to the associative isocortex, relatively sparing the primary sensory, motor, and visual areas. In their clinicopathological study, Braak and Braak distinguished six stages that can be summarized in three: entorhinal, limbic, and isocortical (Fig. 2). The first NFTs consistently appear in the transentorhinal (perirhinal) region (stage I) along with the entorhinal cortex proper, followed by the CA1 region of the hippocampus (stage II). Next, NFTs develop and accumulate in limbic structures such as the subiculum of the hippocampal formation (stage III) and the amygdala, thalamus, and claustrum (stage IV). Finally, NFTs spread to all isocortical areas (isocortical stage), with the associative areas being affected prior and more severely (stage $\mathrm{V}$ ) than the primary sensory, motor, and visual areas (stage VI). A severe involvement of striatum and substantia nigra can occur during the late isocortical stage. Of note, this neurofibrillary degeneration follows a laminar pattern affecting preferentially the stellate neurons of layer II, the superficial portion of layer III, and the large multipolar neurons of layer IV within the entorhinal cortex; the stratum pyramidale of CA1 and subiculum within the hippocampal formation, and the pyramidal neurons of layers III and V within the isocortical areas (Hyman et al. 1984; Arnold et al. 1991; Braak and Braak 1991).

\section{Clinicopathological Correlations}

Multiple clinicopathological studies from different groups have established that the amount and distribution of NFTs correlate with the severity and the duration of dementia (Arriagada et al. 1992a; Bierer et al. 1995; Gómez-Isla et al. 
A. Serrano-Pozo et al.
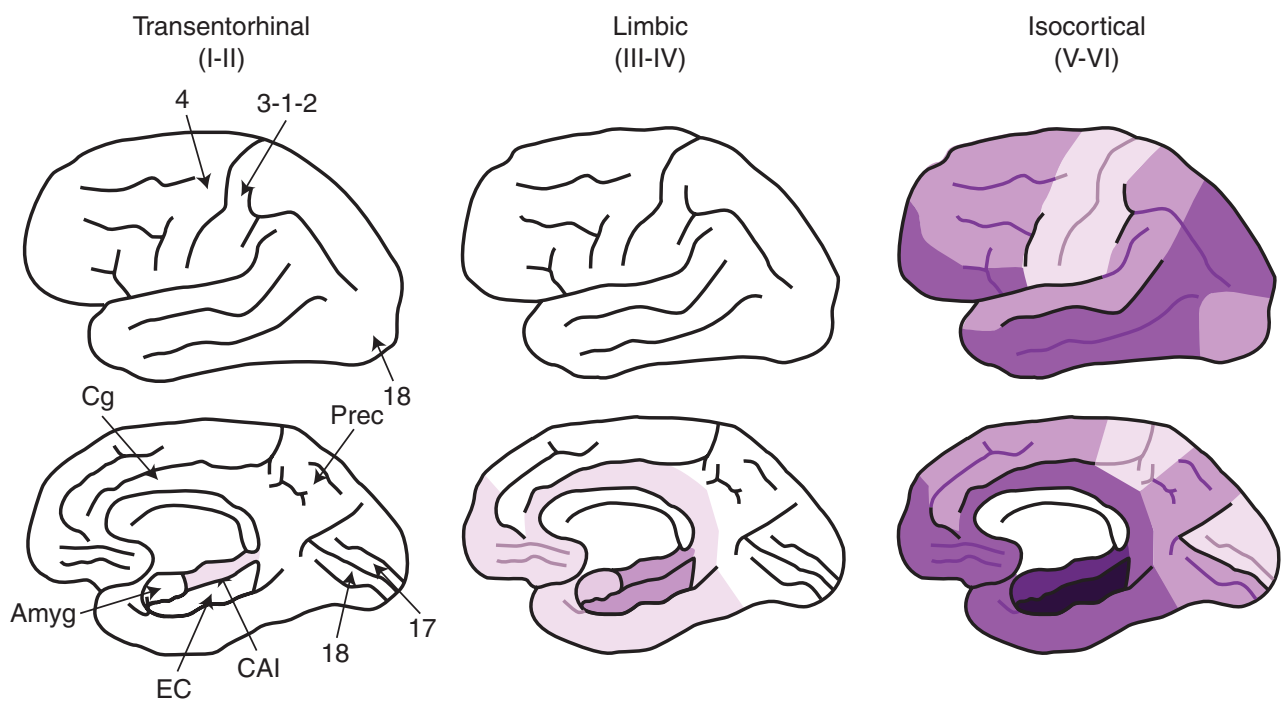

Figure 2. Spatiotemporal pattern of neurofibrillary degeneration. Shading indicates the distribution of NFTs with darker colors representing increasing densities. Amyg = Amygdala; EC = Entorhinal cortex; CA1 = Cornus ammonis 1 hippocampal subfield; $\mathrm{Cg}=$ Cingulate cortex; Prec $=$ Precuneus; $4=$ Primary motor cortex; 3-1-2 = Primary sensory cortex; $17=$ Primary visual cortex; $18=$ Associative visual cortex (data based on Arnold et al. 1991; Braak and Braak 1991; Arrigada et al 1992a,b; Braak et al. 1994).

1997; Giannakopoulos et al. 2003; Ingelsson et al. 2004). Moreover, the selective rather than widespread topographical distribution of NFTs described above matches with the hierarchical neuropsychological profile typical of the AD-type dementia syndrome. The prominent initial impairment of episodic memory characteristic of $\mathrm{AD}$ is explained by the isolation of the medial temporal lobe structures from the association isocortex and the subcortical nuclei because of the ongoing massive neurofibrillary degeneration. Next, the involvement of multimodal high-order association isocortical areas accounts for the progressive impairment of additional cognitive domains, including executive dysfunction (prefrontal cortex), apraxias (parietal cortex), visuospatial navigation deficits (occipitoparietal cortex), visuoperceptive deficits (occipitotemporal cortex), and semantic memory (anterior temporal cortex), giving rise to the full-blown dementia syndrome. By contrast, the late involvement of primary motor, sensory, and visual isocortical areas explains the sparing of motor, sensory, and primary visual functions (Hyman et al. 1984; Arnold et al. 1991; Braak and Braak 1991). However, as discussed below, whether NFT formation is a necessary precursor of the neuronal death in $\mathrm{AD}$ or represents a protective response of damaged neurons (and thus more of a surrogate marker of the ongoing pathological process) is still controversial.

\section{Amyloid Plaques}

\section{Composition}

The senile plaques described by Alois Alzheimer in his original case report result from the abnormal extracellular accumulation and deposition of the amyloid- $\beta$ peptide $(A \beta)$ with 40 or 42 amino acids ( $A \beta 40$ and $A \beta 42$ ), two normal byproducts of the metabolism of the amyloid precursor protein (APP) after its sequential cleavage by the enzymes $\beta$ - and $\gamma$-secretases in neurons. Because of its higher rate of fibrillization and insolubility, $A \beta 42$ is more abundant than $A \beta 40$ within the plaques. 


\section{Morphological Characteristics}

Attempts to understand the evolution of the amyloid plaque after its formation based on morphological criteria gave rise to a number of terms, including "primitive," "classical," and "burn-out" plaques. However, a more practical and widely used morphological classification distinguishes only two types of amyloid plaques-diffuse versus dense-core plaquesbased on their staining with dyes specific for the $\beta$-pleated sheet conformation such as Congo Red and Thioflavin-S. This simpler categorization is relevant to the disease because, unlike diffuse Thioflavin-S negative plaques, Thioflavin-S positive dense-core plaques are associated with deleterious effects on the surrounding neuropil including increased neurite curvature and dystrophic neurites, synaptic loss, neuron loss, and recruitment and activation of both astrocytes and microglial cells (Itagaki et al. 1989; Masliah et al. 1990, 1994; Pike et al. 1995; Knowles et al. 1999; Urbanc et al. 2002; Vehmas et al. 2003). Indeed, diffuse amyloid plaques are commonly present in the brains of cognitively intact elderly people, whereas dense-core plaques, particularly those with neuritic dystrophies, are most often found in patients with $\mathrm{AD}$ dementia. However, the pathological boundaries between normal aging and $\mathrm{AD}$ dementia are not clear-cut and, as we will further discuss below, many cognitively normal elderly people have substantial amyloid burden in their brains.

Electron microscopy studies revealed that the ultrastructure of dense-core plaques is comprised of a central mass of extracelullar filaments that radially extend toward the periphery, where they are intermingled with neuronal, astrocytic, and microglial processes. These neuronal processes, known as dystrophic neurites, often contain packets of paired helical filaments, as well as abundant abnormal mitochondria and dense bodies of probable mitochondrial and lysosomal origin (Kidd 1964; Hirai et al. 2001; Fiala et al. 2007). Plaque-associated neuritic dystrophies represent the most notorious evidence of $A \beta$-induced neurotoxicity and feature many of the pathophysiological processes downstream $A \beta$. Their origin can be axonal or dendritic and their morphology can be either elongated and distorted or bulbous (Su et al. 1993). They can be argyrophylic (Fig. 1C) and Thioflavin-S positive because of the aggregation of $\beta$-sheet pleated tau fibrils, which can also be shown with many phosphotau and conformation-specific tau antibodies (Su et al. 1993, 1994, 1996). Interestingly, dystrophic neurites can also be immunoreactive for APP (Cras et al. 1991; Su et al. 1998). Cytoskeletal abnormalities in dystrophic neurites explain their immunoreactivity for neurofilament proteins ( $\mathrm{Su}$ et al. 1996, 1998; Dickson et al. 1999; Knowles et al. 1999). These cytoskeletal abnormalities can lead to a disruption of the normal axonal transport and, indeed, a subset of dystrophic neurites are positive for mitochondrial porin and chromogranin-A because of the abnormal accumulation of mitochondria and large synaptic vesicles, respectively (Dickson et al. 1999; Woodhouse et al. 2006a; Pérez-Gracia et al. 2008). Moreover, some axonal dystrophic neurites contain either cholinergic, glutamatergic, or gabaergic markers, suggesting a plaqueinduced aberrant sprouting (Benzing et al. 1993; Ferrer et al. 1993; Masliah et al. 2003; Bell et al. 2007). Finally, dystrophic neurites can be displayed with immunohistochemical studies for ubiquitin and lysosomal proteins, indicating that there is a compensatory attempt to degrade and clear the abnormal accumulation of proteins and organelles (Dickson et al. 1990; Barrachina et al. 2006). A less-evident expression of the plaque-induced neuritic changes is the increase in the curvature of neurites located in the proximity of dense-core plaques (Knowles et al. 1999).

\section{Topographic Distribution}

Unlike NFTs, amyloid plaques accumulate mainly in the isocortex. Although the spatiotemporal pattern of progression of amyloid deposition is far less predictable than that of NFTs, in general the allocortex (including entorhinal cortex and hippocampal formation), the basal ganglia, relevant nuclei of the 
A. Serrano-Pozo et al.

brainstem, and the cerebellum, are involved to a lesser extent and later than the associative isocortex. The dissociation between amyloid and NFT burdens in the medial temporal lobe is particularly noticeable. Among the isocortical areas, likewise NFTs, primary sensory, motor, and visual areas tend to be less affected as compared to association multimodal areas. (Arnold et al. 1991; Braak and Braak 1991). Despite this poorer predictability of the progression of amyloid deposition, two staging systems have been proposed. Braak and Braak distinguished three stages: (1) Stage A, with amyloid deposits mainly found in the basal portions of the frontal, temporal, and occipital lobes; (2) Stage $\mathrm{B}$, with all isocortical association areas affected while the hippocampal formation is only mildly involved, and the primary sensory, motor, and visual cortices are devoid of amyloid; and (3) Stage C, characterized by the deposition of amyloid in these primary isocortical areas and, in some cases, the appearance of amyloid deposits in the molecular layer of the cerebellum and subcortical nuclei such as striatum, thalamus, hypothalamus, subthalamic nucleus, and red nucleus (Braak and Braak 1991). Thal et al. proposed a descendent progression of amyloid deposition in five stages: (1) Stage 1 or isocortical; (2) Stage 2, with additional allocortical deposits (entorhinal cortex, hippocampal formation, amygdala, insular, and cingulated cortices); (3) Stage 3, with additional involvement of subcortical nuclei including striatum, basal forebrain cholinergic nuclei, thalamus and hypothalamus, and white matter; (4) Stage 4, characterized by the involvement of brainstem structures, including red nucleus, substantia nigra, reticular formation of the medulla oblongata, superior and inferior colliculi; and (5) Stage 5, with additional amyloid deposits in the pons (reticular formation, raphe nuclei, locus ceruleus) and the molecular layer of the cerebellum (Thal et al. 2002). These five Thal stages can be summarized in three: stage 1 or isocortical; stage 2, allocortical or limbic, and stage 3 or subcortical (Fig. 3).

Amyloid deposits usually involve the six layers of the isocortex, although layers I and VI are usually relatively more spared than layers II-V (Arnold et al. 1991; Braak and Braak 1991). However, in advanced cases it is frequent to observe band-like diffuse amyloid deposits in the subpial surface of the cortex and even a few amyloid deposits in the white matter close to its transition with the cortical layer VI.
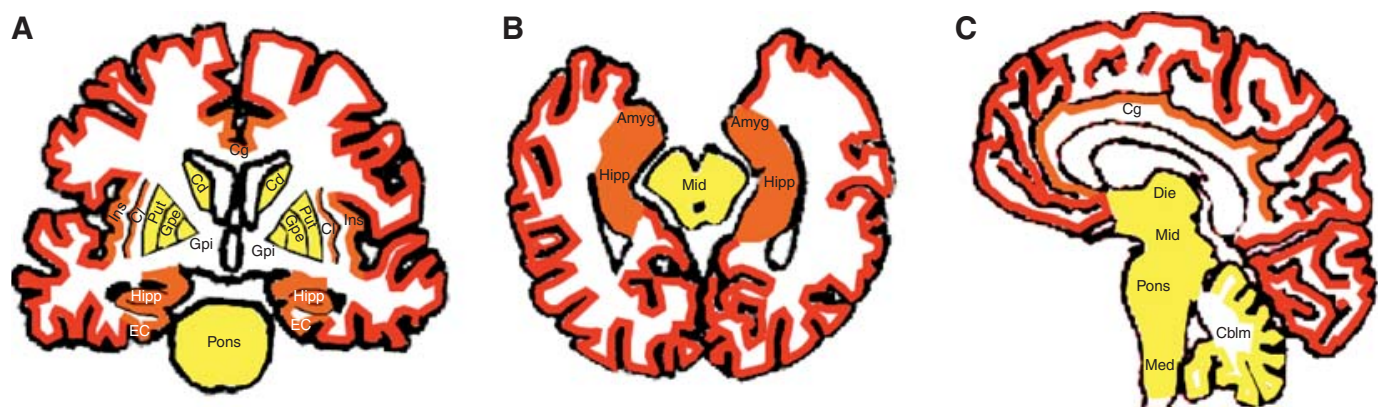

Figure 3. Spatiotemporal pattern of amyloid plaque deposition according to Thal et al. (2002). Coronal (A), axial $(B)$, and sagittal $(C)$ views of the brain. The five Thal stages of amyloid deposition are here summarized in three stages. Amyloid deposits accumulate first in isocortical areas (stage 1 or isocortical, in red), followed by limbic and allocortical structures (stage 2 or limbic, in orange), and in a later stage, by subcortical structures including basal ganglia, selected nuclei in diencephalon and brainstem, and the cerebellar cortex (stage 3 or subcortical, in yellow). Amyg = Amygdala; $\mathrm{EC}=$ Entorhinal cortex; Hipp = Hippocampus; $\mathrm{Cg}=$ Cingulate cortex; $\mathrm{Cd}=$ Caudate nucleus; Put = Putamen; Gpe = Globus pallidus externus; Gpi = Globus pallidus internus; $\mathrm{Cl}=$ Claustrum; Ins = Insular cortex; Die = Diencephalon; Mid = Midbrain; Med = Medulla oblongata; Cblm $=$ Cerebellum. 


\section{Clinicopathological Correlations}

Clinicopathological studies have established that the amyloid burden (either total amyloid plaques, dense-core plaques or only neuritic plaques) does not correlate with the severity or the duration of dementia (Arriagada et al. 1992a, Hyman et al. 1993; Bierer et al. 1995; Gómez-Isla et al. 1997; Giannakopoulos et al. 2003; Ingelsson et al. 2004). Indeed, in a region of early amyloid deposition such as the temporal associative isocortex, the amyloid burden reaches a plateau early after the onset of the cognitive symptoms or even in the preclinical phase of the disease (Ingelsson et al. 2004; Serrano-Pozo et al. 2011) and not even the size of the plaques grows significantly with the progression of the disease (Hyman et al. 1993). However, it is possible that the amount of amyloid measured over the entire cortical mantle does increase during the clinical course of the disease as the distribution of amyloid deposits "spread" following the above stages. Preliminary data from longitudinal amyloid PET imaging studies in living patients have recently supported this possibility (Jack et al. 2009).

\section{Cerebral Amyloid Angiopathy}

\section{Composition}

The amyloid- $\beta$ peptide not only deposits in the brain parenchyma in the form of amyloid plaques but also in the vessel walls in the form of cerebral amyloid angiopathy (CAA). Indeed, the more insoluble and aggregation-prone $\mathrm{A} \beta 42$ peptide tends to accumulate in the core of senile plaques, while the more soluble $\mathrm{A} \beta 40$ peptide is the major constituent of CAA, accumulating mainly in the interstitium between the smooth muscle cells of the tunica media. Although CAA can also appear in isolation (pure CAA), it is more common in the context of $\mathrm{AD}$, with $\approx 80 \%$ of $\mathrm{AD}$ patients showing some degree, usually mild, of CAA at autopsy,

\section{Morphological Characteristics}

The same methods described for the examination of amyloid plaques are valid for CAA, that is Thioflavin-S or Congo red staining or immunohistochemical studies with anti-A $\beta$ antibodies. A morphological staging system has been implemented to describe the severity of CAA within a single vessel: grade 0 or absence of staining; grade 1 or congophilic rim around an otherwise nomal-appearance vessel; grade 2 or complete replacement of the tunica media by congophilic material; grade 3 or cracking of $\geq 50 \%$ of the circumference of the vessel, giving a "vessel-within-vessel" or "double-barrel" appearance; and grade 4 or fibrinoid necrosis of the vessel wall, often accompanied by additional amyloid deposits in the surrounding neuropil ("dyshoric" changes) (Greenberg and Vonsattel 1997). In this severe stage, Prussian blue (Perl's) staining is useful to show hemosiderin-laden macrophages in the parenchyma surrounding CAA-affected vessels, indicative of chronic microbleeds.

\section{Topographic Distribution}

CAA usually affects cortical capillaries, small arterioles and middle-size arteries as well as leptomeningeal arteries, whereas venules, veins, and white-matter arteries are rarely involved. For unknown reasons, posterior parietal and occipital areas are usually more prominently affected than frontal and temporal lobes, and within the same area, leptomeningeal arteries usually show more severe CAA than cortical arteries. A semiquantitative scoring system has been proposed to characterize the severity of CAA within a region of the cortex: $0=$ no Thioflavin-S-stained leptomeningeal or cortical vessels; $1=$ scattered positivity in either leptomeningeal or cortical vessels; $2=$ strong circumferential positivity in at least some vessels either leptomeningeal or cortical; $3=$ widespread circumferential staining in many leptomeningeal and cortical vessels, and $4=$ presence of "dyshoric" perivascular amyloid deposits in addition to score 3 . A global severity score can be obtained by averaging the scores from several regions (Olichney et al. 2000).

\section{Clinicopathological Correlations}

According to the Boston criteria, CAA should be suspected after one or multiple major symptomatic lobar hemorrhages in an elderly patient 
A. Serrano-Pozo et al.

(Knudsen et al. 2001). But in the context of $\mathrm{AD}$, unless it becomes symptomatic because of this hemorrhagic complication, CAA is usually diagnosed at autopsy. However, three independent postmortem longitudinal studies have revealed that the otherwise apparently asymptomatic CAA can also be a synergistic contributor to cognitive decline in AD (MRC CFAS 2001; Pfeifer et al. 2002; Greenberg et al, 2004; Arvanitakis et al. 2011).

\section{Granuovacuolar Degeneration and Hirano Bodies}

Granulovacuolar degeneration (GVD) and Hirano bodies are two poorly understood lesions present in the cytoplasm of hippocampal pyramidal neurons of $\mathrm{AD}$ patients. Although they are increasingly observed with aging in cognitively intact elderly people, these two lesions are more severe and frequent in age-matched AD patients. (Ball 1978; Xu et al. 1992).

GVD consists of the accumulation of large double-membrane bodies. Their origin and significance are uncertain. Early immunohistochemical studies reported immunoreactivity of GVD bodies for cytoskeletal proteins including tubulin, neurofilament proteins and tau (Kahn et al. 1985; Price et al. 1986; Dickson et al. 1987; Bondareff et al. 1991; Mena et al. 1992; Ikegami et al. 1996). Because GVD bodies are also positive for some tau kinases, a role in tangle formation has been proposed (Ghoshal et al. 1999; Leroy et al. 2002; Kannanayakal et al. 2006). Other authors have postulated a role in the apoptotic cell death because of their immunoreactivity for activated caspase-3 (Selznick et al. 1999; Stadelmann et al. 1999; $\mathrm{Su}$ et al. 2002). More recent studies have suggested that these bodies might derive from the endoplasmic reticulum and represent the stress granules that feature the unfolded protein response, because they are positive for several stress kinases (Zhu et al. 2001; Lagalwar et al. 2007; Thakur et al. 2007; Hoozemans et al. 2009). Finally, based on their positivity for ubiquitin and autophagic markers, it has been proposed that these granules are late-stage autophagic vacuoles (Okamoto et al. 1991;
Barrachina et al. 2006; Yamazaki et al. 2010; Funk et al. 2011).

Hirano bodies are eosinophilic rod-like cytoplasmic inclusions relatively common in the stratum lacunosum of the hippocampal CA1 region in the elderly. However, in $\mathrm{AD}$ patients the number of Hirano bodies is abnormally high and they are translocated to the neurons of the stratum pyramidale (Gibson and Tomlison 1977). Although the significance of Hirano bodies in $\mathrm{AD}$ is not completely understood, they are recognized by antibodies against tau, neurofilament proteins, actin, and other cytoskeletal proteins (Goldman 1983; Galloway et al. 1987a,b; Schmidt et al. 1989; Maciver and Harrington 1995; Rossiter et al. 2000). Other immunoreactivities associated with Hirano bodies are inducible nitric oxide synthase (Lee et al. 1999), advanced glycation endproducts (Münch et al. 1998), and the carboxy-terminal fragments of APP (Muñoz et al. 1993).

\section{Glial Responses}

Reactive astrocytes and activated microglial cells are commonly associated to dense-core amyloid plaques, indicating that amyloid- $\beta$ is a major trigger of this glial response (Itagaki et al. 1989; Pike et al. 1995; Vehmas et al. 2003). However, we have recently observed a linear increase in reactive astrocytes and activated microglial cells through the entire disease course despite an early plateau in amyloid deposition in the temporal associative isocortex. Indeed, we found a highly significant positive correlation between both astrocytosis and microgliosis and NFT burden but not between both reactive glial cell types and amyloid burden, suggesting that glial responses are also related to neurofibrillary degeneration (Ingelsson et al. 2004; Serrano-Pozo et al. 2011).

\section{Neuronal Loss}

Neuronal loss is the main pathological substrate of cortical atrophy and, although usually evident in sections stained with hematoxylin and eosin, it can be more readily shown with a Nissl staining or a NeuN immunohistochemistry. Nissl staining (for example with cresyl 
violet) reveals the negatively charged ribosomic RNA present in the ribosomes of the rough endoplasmic reticulum (Nissl substance or granules), giving a dark blue appearance to the perinuclear region of neurons. By contrast, NeuN is a neuronal-specific nuclear antigen, although NeuN immunohistochemistry also stains the perinuclear region and some proximal processes of neurons.

The regional and laminar pattern of neuronal loss matches that of NFTs, but, importantly, within the same region neuronal loss exceeds the numbers of NFTs, so that it is a better correlate of cognitive deficits than the number of NFTs (Gómez-Isla et al. 1996, 1997). Indeed, quantitative stereology-based studies of neurons, iNFTs and eNFTs have concluded that iNFTs can last for up to two decades and that neurons bearing iNFTs might still be viable as evidenced by their positive Nissl staining (Bussiére et al. 2003; Hof et al. 2003). This dissociation between the extent of neuronal loss and that of NFTs suggests that there are least two mechanisms of neuronal death in $\mathrm{AD}$ : one affecting tangle-bearing neurons, that will lead to the appearance of ghost extracellular tangles, and another affecting tangle-free neurons. Although the mechanisms of neuronal death in $\mathrm{AD}$ are beyond the scope of this article, it will be noted that postmortem studies on apoptosis have yielded controversial results, with some studies showing a widespread distribution of apoptotic markers (Troncoso et al. 1996; Su et al. 2001), while others have only reported a scattered distribution (Selznick et al. 1999; Woodhouse et al. 2006b).

\section{Synapse Loss}

Besides neuronal loss, synapse loss is another contributor to the cortical atrophy of the AD brain. Synapse loss in AD was shown with immunohistochemical studies using antibodies against pre- or postsynaptic proteins-typically the presynaptic protein synaptophysin-and with electron microscopy studies.

The spatiotemporal and laminar pattern of synapse loss matches that of neuron loss. Synaptic loss is not only caused by neuronal loss but can exceed the existing neuronal loss within a particular cortical area. This indicates that synapse loss predates neuronal loss and that the remaining neurons become less well connected to their synaptic partners than expected just by the number of viable neurons surviving in a particular circuit. Likely this is why synaptic density is the best correlate of cognitive decline in AD (DeKosky and Scheff 1990; Scheff et al. 1990, 1993, 2007; Terry et al. 1991; Masliah et al. 1994; Ingelsson et al. 2004). Interestingly, an inverse correlation has been observed between synaptic density and the size of remaining synapses as measured by the length of the postsynaptic density. This enlargement of remaining synapses has been interpreted as a compensatory response, rather than as selective loss of small synapses (DeKosky and Scheff 1990; Scheff et al. 1990; Scheff and Price 1993).

\section{CRITERIA FOR THE PATHOLOGICAL DIAGNOSIS OF ALZHEIMER DISEASE}

Of all pathological features described above, amyloid plaques and NFTs are the most characteristic of $\mathrm{AD}$ and, understandably, the criteria for the pathological diagnosis of $\mathrm{AD}$ rely on their amount and/or distribution.

The first pathological criteria for the diagnosis of $\mathrm{AD}$ were based on the highest density of total amyloid plaques (both diffuse and neuritic) in any cortical field, adjusted for age so that the older the patient at death, the greater the density required for diagnosis (Khachaturian 1985). The presence of NFTs was not required and diffuse plaques_-relatively frequent in nondemented elderly people-had the same consideration as neuritic plaques. Although meritorious, these criteria were soon abandoned because, despite a very high sensitivity to diagnose $\mathrm{AD}$ dementia, they lacked sufficient specificity (Geddes et al. 1997). In 1991, the Consortium to Establish a Registry for Alzheimer Disease (CERAD) proposed more specific diagnostic criteria by emphasizing the importance of neuritic plaques over diffuse plaques (Mirra et al. 1991, 1997). CERAD criteria use a semiquantitative score of the density of neuritic plaques in the most severely affected region of 
A. Serrano-Pozo et al.

the isocortex (frontal, temporal, or parietal) and the patient's age at death to obtain an age-related plaque score. This score is then integrated with clinical information regarding the presence or absence of dementia to establish one of three levels of certainty that dementia is explained by the $\mathrm{AD}$ pathological changes: possible, probable, and definite. A diagnosis of $\mathrm{AD}$ is made if the criteria for probable or definite $\mathrm{AD}$ are met. Although higher than that of Khachaturian criteria, the specificity of CERAD criteria proved to be still insufficient because they did not incorporate the scoring of the severity of NFTs (Geddes et al. 1997). By contrast, the use of Braak and Braak staging of NFTs alone-with the isocortical stages $\mathrm{V}$ and VI as criteria of definite $\mathrm{AD}$ - showed a high specificity at the expense of a low sensitivity (Geddes et al. 1997).

Current pathological criteria for $\mathrm{AD}$ were defined in 1997 by a workshop of the National Institute of Aging and the Reagan Institute. The NIA-RI consensus recommendations combine the CERAD semiquantitative score of neuritic plaques and the Braak and Braak staging of NFTs to distinguish three probabilistic diagnostic categories: (1) high likelihood, if there are frequent neuritic plaques (CERAD definite) and abundant isocortical NFTs (Braak stage V/ $\mathrm{VI})$; (2) intermediate likelihood, if there are moderate neuritic plaques (CERAD probable) and NFTs are restricted to limbic regions (Braak III/IV), and (3) low likelihood, if there are infrequent neuritic plaques (CERAD possible) and NFTs are restricted to the entorhinal cortex and/or hippocampus (Braak I/II). A diagnosis of $\mathrm{AD}$ is made when the criteria for intermediate or high likelihood of AD are met and the patient had a clinical history of dementia (NIA-RI Consensus 1997). Because experience has revealed infrequent cases with many $\mathrm{AD}$ pathological lesions but no or few cognitive symptoms (and vice versa) and these circumstances were not addressed by the NIA-RI consensus workgroup, these diagnostic criteria are currently under review.

Both CERAD and NIA-RI criteria also incorporated the assessment of other pathologies, particularly vascular and Lewy body diseases, already recognizing the high prevalence of mixed pathologies underlying dementia in elderly people, a circumstance well documented by more recent longitudinal community-based clinicopathological studies (MRC CFAS 2001; Schneider et al. 2007). Thus, in many practical instances, the CERAD criteria for "possible $\mathrm{AD}$ ” and the NIA-RI criteria for "intermediate probability of AD" are not only based on a moderate amount and distribution of AD pathology but also on the coexistence of vascular or Lewy body pathology with sufficient severity to contribute to the patient's dementia.

\section{NEUROPATHOLOGY OF MILD COGNITIVE IMPAIRMENT AND EARLY ALZHEIMER DISEASE}

Clinicopathological correlation studies have taught us that at the moment of the clinical diagnosis, patients with $\mathrm{AD}$-type dementia often already have a Braak stage V or VI of neurofibrillary degeneration and a substantial and widespread synaptic and neuronal loss. To anticipate the clinical diagnosis of $\mathrm{AD}$ before the stage of full-blown dementia, a new clinical construct was needed. Petersen et al. proposed the concept of "mild cognitive impairment" (MCI) as a new diagnostic entity for the transition between normal aging and $\mathrm{AD}$ dementia. Patients with MCI have already some cognitive complaints that are detectable with the appropriate cognitive tests and represent a decline from a previous higher baseline level but that, unlike the definition of dementia, do not interfere with their activities of daily life. Importantly, MCI patients have an increased risk of developing dementia, which has been reported between $10 \%$ and 15\% per year (Petersen et al. 1999, 2001; Petersen 2004).

Autopsy studies on MCI patients are scarce but they have reproducibly found a stage of $\mathrm{AD}$ pathology intermediate between cognitively intact subjects and demented patients, particularly regarding neurofibrillary degeneration, that is consistent with the idea of a transition phase between normal aging and definite AD (Jicha et al. 2006; Markesbery et al. 2006; Petersen et al. 2006; Schneider et al. 2009). Specifically, MCI patients usually have 
a moderate number of neuritic plaques and a limbic stage of NFTs (Braak stage III or IV), fitting into the NIA-RI category of intermediate likelihood of $\mathrm{AD}$ (sufficient to cause dementia) and providing a pathological validation for this clinical construct. Along the same lines, patients with a Clinical Dementia Rating score of 0.5 (equivalent to $\mathrm{MCI}$ or very mild $\mathrm{AD}$ ) have already a $\approx 30 \%$ of neuron loss in the entorhinal cortex compared to cognitively intact controls $(\mathrm{CDR}=0)$, but still no evident neuronal loss in the superior temporal sulcus (Gómez-Isla et al. 1996, 1997). Moreover, electron microscopy studies have shown that MCI patients also have an intermediate number of synapses between nondemented controls and mild $\mathrm{AD}$ patients in the hippocampus, further indicating that many individuals with the clinical symptoms of MCI have early AD (Scheff et al. 2006, 2007). Of note, a paradoxical, presumably compensatory, up-regulation in the density of presynaptic glutamatergic boutons has been reported in the frontal cortex of MCI patients compared to nondemented controls and mild AD patients (Bell et al. 2007).

Although AD was the most common pathological diagnosis underlying MCI in the above case series, it should be noted that there was a high degree of pathological heterogeneity underlying the clinical diagnosis of MCI, with vascular disease, Lewy body disease, argyrophilic grain disease, and hippocampal sclerosis as major concurrent or alternative pathologies (Jicha et al. 2006; Petersen et al. 2006; Schneider et al.2009). In addition, in the largest study a high proportion (up to 25\%) of MCI patients had no pathology at autopsy (Schneider et al. 2009). Finally, no significant pathological differences have been observed between the amnestic and the nonamnestic subtypes of MCI nor in their pathological outcome after conversion to dementia (Jicha et al. 2006; Schneider et al. 2009).

\section{ALZHEIMER NEUROPATHOLOGY IN "NORMAL AGING"}

Longitudinal prospective clinicopathological studies in nondemented elderly people have revealed that up to $45 \%$ of nondemented elderly would meet the NIA-RI criteria for AD had they been demented, usually the intermediate likelihood category of these criteria, and rarely the high likelihood category (Schmitt et al. 2000; Knopman et al. 2003; Bennet et al. 2006; Price et al. 2009; Schneider et al. 2009). Moreover, the pattern of regional distribution of pathological changes in nondemented controls matches that of $\mathrm{AD}$ patients (Arriagada et al. 1992b). Thus, mounting evidence from clinicopathological studies support the view that $\mathrm{AD}$ is a continuous spectrum between asymptomatic lesions in cognitively normal elderly and dementia, with MCI as a transition phase between these two ends.

The apparent dissociation between $\mathrm{AD}$ pathology and cognitive status in some elderly people is remarkable because these so-called "high-pathology nondemented controls" or "individuals with asymptomatic $\mathrm{AD}$ " seem to be resilient to the neurotoxic effects of amyloid plaques and NFTs and to contradict the aforementioned positive correlation between NFT burden and cognitive decline. Understanding the biochemical and morphological substrates of this resilience to cognitive decline in the presence of abundant AD pathology might be crucial to discover new therapeutic targets for the disease. As expected from the highly significant clinicopathological correlations of synaptic and neuronal loss in $\mathrm{AD}$, high-pathology controls have preserved synaptophysin levels compared to $\mathrm{AD}$ patients with a similar burden of plaques and NFTs (Lue et al. 1996), and they do not seem to have significant neuronal loss, not even in vulnerable regions such as the entorhinal cortex and the hippocampus (Price et al. 2001; West et al. 2004). Moreover, they have lower levels of neuroinflammatory markers than pathology-matched AD patients (Lue et al. 1996). This resistance to $\mathrm{AD}$ pathology has also been related to a nucleolar, nuclear, and cell body hypertrophy of the hippocampal and cortical neurons, suggestive of a compensatory metabolic activation to face the neurotoxic effects of $\mathrm{AD}$ lesions (Riudavets et al. 2007; Iacono et al. 2008). In keeping with these pathological reports, a MRI-neuropathological correlation study revealed larger brain and hippocampal 
A. Serrano-Pozo et al.

volumes in high-pathology controls than in pathology-matched demented patients, further supporting the preservation of both neurons and synapses (Erten-Lyons et al. 2009).

\section{OVERLAP OF AD WITH LEWY BODY DISEASE}

Alzheimer disease and Parkinson's disease (PD) are the leading causes of dementia and movement disorders in the aging population. It is estimated that over 10 million people live with these devastating neurological conditions in the United States. It is estimated that over 10 million people live with these devastating neurological conditions in the United States, and that this country alone will see a $50 \%$ annual increase of AD and PD by the year 2025 (Herbert et al. 2001).

$\mathrm{PD}$ and $\mathrm{AD}$ are two distinct clinicopathological entities. While in AD, abnormal accumulation of misfolded $A \beta$ protein in the neocortex and limbic system is thought to be responsible for the neurodegenerative pathology (Selkoe 1990; Sisodia and Price 1995), intracellular accumulation of $\alpha$-synuclein has been centrally implicated in the pathogenesis of PD (Spillantini et al. 1997; Hashimoto et al. 1998; Trojanowski and Lee 1998). In AD, A $\beta$ protein accumulates in the intracellular (LaFerla et al. 1995; Skovronsky et al. 1998) and extracellular space, leading to the formation of plaques, whereas intracellular polymerization of phosphorylated cytoskeletal molecules such as tau results in the formation of neurofibrillary tangles (Greenberg and Davies 1990; Lee et al. 2001). In PD, intracellular accumulation of $\alpha$-synuclein — an abundant synaptic terminal protein (Iwai et al. 1995) —results in the formation of characteristic inclusions called Lewy bodies (LBs) (Fig. 1F) (Spillantini et al. 1997; Wakabayashi et al. 1997; Takeda et al. 1998). The new consortium criteria for the classification of Lewy body diseases (LBD) recognizes two clinical entities, the first denominated dementia with LBs (DLB) and the second PD dementia (PDD) (McKeith et al. 1996; Aarsland et al. 2004; Burn 2006; McKeith 2006; Lippa et al. 2007). While in patients with
DLB, the clinical presentation is of dementia followed by parkinsonism, in patients with PDD the initial signs are of parkinsonism followed by dementia (Litvan et al. 1998; Janvin et al. 2006; McKeith 2006). Interestingly, the brains of patients with DLB and PDD display very similar pathology, with the exception that recent studies have shown extensive deposition of $A \beta$ and $\alpha$-synuclein in the striatum and hippocampus in DLB compared to only $\alpha$-synuclein in PDD cases (Duda et al. 2002; Jellinger and Attems 2006). Because of the implications for the management and treatment of parkinsonism and dementia in patients with PD and DLB, loss of dopaminergic neurons in the midbrain (Dickson et al. 1994; Tsuboi and Dickson 2005) and cholinergic cells in the nucleus basalis of Meynert have been characterized in detail (Perry et al. 1978; Hansen et al. 1990). Although the severity of the neuronal loss within these subcortical regions might explain some of the neurological deficits in patients with PD and DLB, the neuronal populations responsible for the more complex cognitive and psychiatric alterations have not been completely characterized. Abnormal accumulation of $\alpha$-synuclein in the CA2-3 region of the hippocampus (Harding and Halliday 2001; Bertrand et al. 2004), insula, amygdala and cingulate cortex has been shown to be an important neuropathological feature (Dickson et al. 1994; Spillantini et al. 1997; Trojanowski et al. 1998; Aarsland et al. 2004).

Remarkably, despite being initially considered distinct clinicopathological conditions, several studies have now confirmed that the clinical features and the pathology of $\mathrm{AD}$ and PD can overlap (McKeith 2000, 2006; Lippa et al. 2007). Approximately $25 \%$ of all patients with $\mathrm{AD}$ develop parkinsonism, and about $50 \%$ of all cases of PD develop AD-type dementia after 65 years of age (Hansen et al. 1990). Moreover, $70 \%$ of patients with sporadic AD display the formation of $\alpha$-synuclein-positive LB-like inclusions in the amygdala and limbic structures (Lippa et al. 1998; Trojanowski et al. 1998; Hamilton 2000). Similarly, in patients with familial AD (FAD) and Down syndrome, LB-like pathology and parkinsonism have 
been reported (Lippa et al. 1999). Last, as mentioned above, the single most important neuropathological finding that distinguishes PDD from DLB is the presence of $A \beta$ deposits in the striatum (Duda et al. 2002) and in the hippocampus (Masliah et al. 1993a).

A number of studies provide extensive support for an interaction between pathogenic pathways in $\mathrm{AD}$ and $\mathrm{LBD}$ and argue against a coincidental concurrence of both disorders (i.e., merely because of their high prevalence in the elderly). FAD cases with presenilin mutations that present with significant LB pathology strongly support an interaction between $A \beta$ and $\alpha$-synuclein (Rosenberg 2005; Snider et al. 2005; Leverenz et al. 2006). Although plaques, tangles and LBs are useful neuropathological and diagnostic markers of these disorders, the initial injury that results in the cognitive and movement alterations is likely the damage of the synaptic terminals in selected circuitries (DeKosky and Scheff 1990; Masliah and Terry 1993; Masliah et al. 1994, 2001a, Klucken et al. 2003). Several lines of investigation support the notion that oligomeric forms of $A \beta$ and $\alpha$ synuclein, rather than the polymers and fibrils associated with plaques and LBs, accumulate in the neuronal membranes and lead to the characteristic synaptic pathology (Lambert et al. 1998; Conway et al. 2000; Lashuel et al. 2002; Haass and Selkoe 2007; Kramer and Schulz-Schaeffer 2007; Koffie et al. 2009; Scott et al. 2010). Some studies have shown that underlying interactions between $\alpha$-synuclein and $A \beta$ play a fundamental role in the pathogenesis of LBD (Lippa et al. 1998; Hashimoto et al. 2000; Masliah et al. 2001b, Pletnikova et al. 2005). Specifically, A $\beta$ promotes the oligomerization and toxic conversion of $\alpha$-synuclein (Masliah et al. 2001b; Mandal et al. 2006), A $\beta$ exacerbates the deficits associated with $\alpha$-synuclein accumulation, $A \beta$ and $\alpha$-synuclein colocalize in membrane and caveolar fractions, and $A \beta$ stabilizes $\alpha$-synuclein multimers that might form channel-like structures in the membrane (Tsigelny et al. 2007, 2008). Both lysosomal leakage (Nixon and Cataldo 2006) and oxidative stress (Smith et al. 1996) appear to be involved in the process of neurotoxicity and pathological interactions between $A \beta$ and $\alpha$-synuclein (Rockenstein et al. 2005).

Therefore, it is possible that the combined effects of $\alpha$-synuclein and $A \beta$ might lead to synaptic damage and selective degeneration of neurons in the neocortical, limbic, and subcortical regions. A more precise mapping of the neuronal populations affected in these regions is needed to understand the cellular basis for the characteristic cognitive dysfunction in PDD and DLB and to develop new treatments for these conditions.

\section{CONCLUSIONS}

Classical neuropathological lesions including senile amyloid plaques and neurofibrillary tangles define $\mathrm{AD}$ but they likely represent the "tip of the iceberg" of the pathological alterations that cause the cognitive decline associated with $\mathrm{AD}$. Indeed, the development of new biomarkers and imaging tools has made evident that these neuropathological stigmata of $\mathrm{AD}$ begin to accumulate a decade or more prior to a clinical diagnosis of dementia. Synaptic loss, plasticity changes, neuronal loss, and the presence of soluble microscopic oligomeric forms of $A \beta$ and even of tau, likely contribute to the progressive neural system failure that occurs over decades. An understanding of this natural history of the disease is critical to design primary or secondary prevention strategies to halt the disease progression before the damage to the neural system becomes irreversible.

\section{ACKNOWLEDGMENTS}

This work was funded by the National Institutes of Health grants AG5131, AG18840, AG22074, NS057096, and AG10435 (to E.M.), and P50AG05134 and AG08487 (to B.T.H. and M.P.F.). A.S.P. was supported with a Research Fellowship from Fundación Alfonso Martín Escudero (Madrid, Spain).

\section{REFERENCES}

Aarsland D, Ballard CG, Halliday G. 2004. Are Parkinson's disease with dementia and dementia with Lewy bodies the same entity? J Geriatr Psychiatry Neurol 17: 137-145. 
A. Serrano-Pozo et al.

Arnold SE, Hyman BT, Flory J, Damasio AR, Van Hoesen GW. 1991. The topographical and neuroanatomical distribution of neurofibrillary tangles and neuritic plaques in the cerebral cortex of patients with Alzheimer's disease. Cereb Cortex 1: 103-116.

Arriagada PV, Growdon JH, Hedley-Whyte ET, Hyman BT. 1992a. Neurofibrillary tangles but not senile plaques parallel duration and severity of Alzheimer's disease. Neurology 42: 631-639.

Arriagada PV, Marzloff K, Hyman BT. 1992b. Distribution of Alzheimer-type pathologic changes in non-demented elderly individuals matches the pattern in Alzheimer's disease. Neurology 42: 1681-1688.

Arvanitakis Z, Leurgans SE, Wang Z, Wilson RS, Bennet DA, Schneider JA. 2011. Cerebral amyloid angiopathy pathology and cognitive domains in older persons. Ann Neurol 69: $320-327$.

Augustinack JC, Schneider A, Mandelkow EM, Hyman BT. 2002. Specific tau-phosphorylation sites correlate with severity of neuronal cytopathology in Alzheimer's disease. Acta Neuropathol 103: 26-35.

Ball MJ, Nuttal K. 1978. Topographic distribution of neurofibrillary tangles and granulovacuoles in hippocampal cortex of aging and demented patients. A quantitative study. Acta Neuropathol 42: 73-80.

Barrachina M, Maes T, Buesa C, Ferrer I. 2006. Lysosomeassociated membrane protein 1 (LAMP-1) in Alzheimer's disease. Neuropathol Appl Neurobiol 32: 505-516.

Beach T, Walker R, McGeer E. 1989. Patterns of gliosis in Alzheimer's disease and aging cerebrum. Glia 2: 420-436.

Bell KFS, Bennet DA, Cuello AC. 2007. Paradoxical upregulation of glutamatergic presynaptic boutons during mild cognitive impairment. J Neurosci 27: 10810-10817.

Bennet DA, Schneider JA, Arvanitakis Z, Kelly JF, Aggarwal NT, Shah RC, Wilson RS. 2006. Neuropathology of older persons without cognitive impairment from two community-based studies. Neurology 66: 1837-1844.

Benzing WC, Ikonomovic MD, Brady DR, Mufson EJ, Armstrong DM. 1993. Evidence that transmitter-containing dystrophic neurites precede paired helical filament and Alz-50 formation within senile plaques in the amygdala of nondemented elderly and patients with Alzheimer's disease. J Comp Neurol 334: 176-191.

Bertrand E, Lechowicz W, Szpak GM, Lewandowska E, Dymecki J, Wierzba-Bobrowicz T. 2004. Limbic neuropathology in idiopathic Parkinson's disease with concomitant dementia. Folia Neuropathol 42: 141-150.

Bierer LM, Hof PR, Purohit DP, Carlin L, Schneider J, Davis KL, Perl DP. 1995. Neocortical neurofibrillary tangles correlate with dementia severity in Alzheimer's disease. Arch Neurol 52: 81-88.

Bondareff W, Wischik CM, Novak M, Roth M. 1991. Sequestration of tau by granulovacuolar degeneration in Alzheimer's disease. Am J Pathol 139: 641-647.

Braak H, Braak E. 1991. Neuropathological stageing of Alzheimer-related changes. Acta Neuropathol 82: 239-259.

Braak H, Del Tredici K. 2011. The pathological process underlying Alzheimer's disease in individuals under thirty. Acta Neuropathol 121: 171-181.

Braak E, Braak H, Mandelkow EM. 1994. A sequence of cytoskeleton changes related to the formation of neurofibrillary tangles and neuropil threads. Acta Neuropathol 87: 554-567.

Braak H, Alafuzoff I, Arzberger T, Kretzschmanr H, Del Tredici K. 2006. Staging of Alzheimer disease-associated neurofibrillary pathology using paraffin sections and immunhistochemistry. Acta Neuropathol 112: 389-404.

Burn DJ. 2006. Parkinson's disease dementia: What's in a Lewy body? J Neural Transm Suppl 70: 361-365.

Bussière T, Gold G, Kövari E, Giannakopoulos P, Bouras C, Perl DP, Morrison JH, Hof PR. 2003. Stereologic analysis of neurofibrillary tangle formation in prefrontal cortex area 9 in aging and Alzheimer's disease. Neuroscience 117: $577-592$.

Carmel G, Mager EM, Binder LI, Kuret J. 1996. The structural basis of monoclonal antibody Alz50's selectivity for Alzheimer's disease pathology. J Biol Chem 271: 32789-32795.

Coleman MP, Perry VH. 2002. Axon pathology in neurological disease: A neglected therapeutic target. Trends Neurosci 25: 532-537.

Conway KA, Lee SJ, Rochet JC, Ding TT, Williamson RE, Lansbury PT Jr. 2000. Acceleration of oligomerization, not fibrillization, is a shared property of both $\alpha$-synuclein mutations linked to early-onset Parkinson's disease: Implications for pathogenesis and therapy. Proc Natl Acad Sci 97: 571-576.

Cras P, Kawai M, Lowery D, Gonzalez-DeWhitt P, Greenberg B, Perry G. 1991. Senile plaque neurites in Alzheimer disease accumulate amyloid precursor protein. Proc Natl Acad Sci 88: 7552-7556.

Crews L, Masliah E. 2010. Molecular mechanisms of neurodegeneration in Alzheimer's disease. Hum Mol Genet 19: R12-R20.

Crews L, Rockenstein E, Masliah E. 2010. APP transgenic modeling of Alzheimer's disease: Mechanisms of neurodegeneration and aberrant neurogenesis. Brain Struct Funct 214: 111-126.

Crowther RA. 1991. Straight and paired helical filaments in Alzheimer disease have a common structural unit. Proc Natl Acad Sci 88: 2288-2292.

de Calignon A, Spires-Jones TL, Pitstick R, Carlson GA, Hyman BT. 2009. Tangle-bearing neurons survive despite disruption of membrane integrity in a mouse model of tauopathy. J Neuropathol Exp Neurol 68: 757-761.

de Calignon A, Fox LM, Pitstick R, Carlson GA, Bacskai BJ, Spires-Jones TL, Hyman BT. 2010. Caspase activation precedes and leads to tangles. Nature 464: 1201-1204.

DeKosky ST, Scheff SW. 1990. Synapse loss in frontal cortex biopsies in Alzheimer's disease: Correlation with cognitive severity. Ann Neurol 27: 457-464.

DeKosky ST, Scheff SW, Styren SD. 1996. Structural correlates of cognition in dementia: Quantification and assessment of synapse change. Neurodegeneration 5: 417-421.

Dickerson BC, Bakkour A, Salat DH, Feczko E, Pacheco J, Greve DN, Grodstein F, Wright CI, Blacker D, Rosas $\mathrm{HD}$, et al. 2009. The cortical signature of Alzheimer's disease: Regionally specific cortical thinning relates to symptom severity in very mild to mild $\mathrm{AD}$ dementia and is detectable in asymptomatic amyloid-positive individuals. Cereb Cortex 19: 497-510. 
Dickerson BC, Stoub TR, Shah RC, Sperling RA, Killiany RJ, Albert MS, Hyman BT, Blacker D, Detoledo-Morrell L. 2011. Alzheimer-signature MRI biomarker predicts AD dementia in cognitively normal adults. Neurology 76: 1395-1402.

Dickson DW, Ksiezak-Reding H, Davies P, Yen SH. 1987. A monoclonal antibody that recognizes a phosphorylated epitope in Alzheimer neurofibrillary tangles, neurofilaments and tau proteins immunostains granulovacuolar degeneration. Acta Neuropathol 73: 254-258.

Dickson DW, Wertkin A, Mattiace LA, Fier E, Kress Y, Davies P, Yen SH. 1990. Ubiquitin immunoelectron microscopy of dystrophic neurites in cerebellar senile plaques of Alzheimer's disease. Acta Neuropathol 79: 486-493.

Dickson DW, Schmidt ML, Lee VM, Zhao ML, Yen SH, Trojanowski JQ. 1994. Immunoreactivity profile of hippocampal CA2/3 neurites in diffuse Lewy body disease. Acta Neuropathol 87: 269-276.

Dickson TC, King CE, McCormack GH, Vickers JC. 1999. Neurochemical diversity of dystrophic neurites in the early and late stages of Alzheimer's disease. Exp Neurol 1: $100-110$.

Duda JE, Giasson BI, Mabon ME, Lee VM, Trojanowski JQ. 2002. Novel antibodies to synuclein show abundant striatal pathology in Lewy body diseases. Ann Neurol 52: 205-210.

Duda JE, Giasson B, Lee V-M, Trojanowski JQ. 2003. Is the initial insult in Parkinson's disease and Dementia with Lewy bodies a neuritic dystrophy? Ann NY Acad Sci 991: 295 .

Erten-Lyons D, Woltjer RL, Dodge H, Nixon R, Vorobik R, Calvert JF, Leahy M, Montine T, Kaye J. 2009. Factors associated with resistance to dementia despite high Alzheimer disease pathology. Neurology 72: 354-360.

Ferrer I, Zújar MJ, Rivera R, Soria M, Vidal A, Casas R. 1993. Parvalbumin-immunoreactive dystrophic neurites and aberrant sprouts in the cerebral cortex of patients with Alzheimer's disease. Neurosci Lett 158: 163-166.

Fiala JC, Feinberg M, Peters A, Barbas H. 2007. Mitochondrial degeneration in dystrophic neurites of senile plaques may lead to extracellular deposition of fine filaments. Brain Struct Funct 212: 195-207.

Funk KE, Mrak RE, Kuret J. 2011. Granulovacuolar degeneration bodies of Alzheimer's disease resemble late-stage autophagic organelles. Neuropathol Appl Neurobiol 37: 295-306.

Galloway PG. Perry G, Gambetti P. 1987a. Hirano bodies filaments contain actin and actin-associated proteins. J Neuropathol Exp Neurol 46: 185-199.

Galloway PG, Perry G, Gambetti P. 1987b. Hirano bodies contain tau protein. Brain Res 403: 337-340.

Geddes JW, Tekirian TL, Soultanian NS, Ashford JW, Davis DG, Markesbery WR. 1997. Comparison of neuropathologic criteria for the diagnosis of Alzheimer's disease. Neurobiol Aging 18: S99-S105.

Ghoshal N, Smiley JF, DeMaggio AJ, Hoekstra MF, Cochran EJ, Binder LI, Kuret J. 1999. A new molecular link between fibrillar and granulovacuolar lesions of Alzheimer's disease. Am J Pathol 155: 1163-1172.

Giannakopoulos P, Herrmann FR, Bussière T, Bouras C, Kövari E, Perl DP, Morrison JH, Gold G, Hof PR. 2003.
Tangle and neuron numbers, but not amyloid load, predict cognitive status in Alzheimer's disease. Neurology 60: 1495-1500.

Gibson PH, Tomlison BE. 1977. Numbers of Hirano bodies in the hippocampus of normal and demented people with Alzheimer's disease. J Neurol Sci 33: 199-206.

Glabe CC. 2005. Amyloid accumulation and pathogensis of Alzheimer's disease: Significance of monomeric, oligomeric and fibrillar A . Subcell Biochem 38: 167-177.

Goldman JE. 1983. The association of actin with Hirano bodies. J Neuropathol Exp Neurol 42: 146-152.

Gómez-Isla T, Price JL, McKeel DW Jr, Morris JC, Growdon JH, Hyman BT. 1996. Profound loss of layer II entorhinal cortex neurons occurs in very mild Alzheimer's disease. J Neurosci 16: 4491-4500.

Gómez-Isla T, Hollister R, West H, Mui S, Growdon JH, Petersen RC, Parisi JE, Hyman BT. 1997. Neuronal loss correlates with but exceeds neurofibrillary tangles in Alzheimer's disease. Ann Neurol 41: 17-24.

Greenberg SG, Davies P. 1990. A preparation of Alzheimer paired helical filaments that displays distinct tau proteins by polyacrylamide gel electrophoresis. Proc Natl Acad Sci 87: $5827-5831$.

Greenberg SM, Vonsattel JPG. 1997. Diagnosis of cerebral amyloid angiopathy: Sensitivity and specificity of cortical biopsy. Stroke 28: 1418-1422.

Greenberg SM, Gurol ME, Rosand J, Smith EE. 2004. Amyloid angiopathy-related vascular cognitive impairment. Stroke 35: 2616-2619.

Grutzendler J, Helmin K, Tsai J, Gan WB. 2007. Various dendritic abnormalities are associated with fibrillar amyloid deposits in Alzheimer's disease. Ann NY Acad Sci 1097: $30-39$.

Guillozet AL, Weintraub S, Mash DC, Mesulam MM. 2003. Neurofibrillary tangles, amyloid, and memory in aging and mild cognitive impairment. Arch Neurol 60: $729-736$.

Guillozet-Bongaarts AL, García-Sierra F, Reynolds MR, Horowitz PM, Fu Y, Wang T, Cahill ME, Bigio EH, Berry RW, Binder LI. 2005. Tau truncation during neurofibrillary tangle evolution in Alzheimer's disease. Neurobiol Aging 26: 1015-1022.

Haass C, Selkoe DJ. 2007. Soluble protein oligomers in neurodegeneration: Lessons from the Alzheimer's amyloid ß-peptide. Nat Rev Mol Cell Biol 8: 101-112.

Hamilton RL. 2000. Lewy bodies in Alzheimer's disease: A neuropathological review of 145 cases using $\alpha$-synuclein immunohistochemistry. Brain Pathol 10: 378-384.

Hansen L, Salmon D, Galasko D, Masliah E, Katzman R, DeTeresa R, Thal L, Pay MM, Hofstetter R, Klauber M, et al. 1990. The Lewy body variant of Alzheimer's disease: A clinical and pathologic entity. Neurology 40: 1-8.

Harding AJ, Halliday GM. 2001. Cortical Lewy body pathology in the diagnosis of dementia. Acta Neuropathol 102: $355-363$.

Harris JA, Devidze N, Verret L, Ho K, Halabisky B, Thwin MT, Kim D, Hamto P, Lo I, Yu GQ, et al. 2010a. Transsynaptic progression of amyloid- $\beta$-induced neuronal dysfunction within the entorhinal-hippocampal network. Neuron 68: $428-441$. 


\section{A. Serrano-Pozo et al.}

Harris JA, Devidze N, Halabisky B, Lo I, Thwin MT, Yu GQ Bredesen DE, Masliah E, Mucke L. 2010b. Many neuronal and behavioral impairments in transgenic mouse models of Alzheimer's disease are independent of caspase cleavage of the amyloid precursor protein. J Neurosci 30: $372-381$.

Hashimoto M, Hernandez-Ruiz S, Hsu L, Sisk A, Xia Y, Takeda A, Sundsmo M, Masliah E. 1998. Human recombinant NACP $/ \alpha$-synuclein is aggregated and fibrillated in vitro: Relevance for Lewy body disease. Brain Res 799: 301-306.

Hashimoto M, Takenouchi T, Mallory M, Masliah E, Takeda A. 2000. The role of NAC in amyloidogenesis in Alzheimer's disease. Am J Pathol 156: 734-736.

Hebert LE, Beckett LA, Scherr PA, Evans DA. 2001. Annual incidence of Alzheimer disease in the United States projected to the years 2000 through 2050. Alzheimer Dis Assoc Disord 15: 169-173.

Higuchi M, Lee VM, Trojanowski JQ. 2002. Tau and axonopathy in neurodegenerative disorders. Neuromolecular Med 2: $131-150$.

Hirai K, Aliev G, Nunomura A, Fujioka H, Russell RL, Atwood CS, Johnson AB, Kress Y, Vinters HV, Tabaton $\mathrm{M}$, et al. 2001. Mitochondrial abnormalities in Alzheimer's disease. J Neurosci 21: 3017-3023.

Hof PR, Bussière T, Gold G, Kövari E, Giannakopoulos P, Bouras C, Perl DP, Morrison JH. 2003. Stereologic evidence for persistence of viable neurons in layer II of the entorhinal cortex and the CAl field in Alzheimer disease. J Neuropathol Exp Neurol 62: 55-67.

Hoozemans JJ, van Haastert ES, Nijholt DA, Rozemuller AJ, Eikelenboom P, Scheper W. 2009. The unfolded protein response is activated in pretangle neurons in Alzheimer's disease hippocampus. Am J Pathol 174: 1241-1251.

Hyman BT, Van Hoesen GW, Damasio AR, Barnes CL. 1984. Alzheimer's disease: Cell-specific pathology isolates the hippocampal formation. Science 225: 1168-1170.

Hyman BT, Van Hoesen GW, Kromer LJ, Damasio AR. 1986. Perforant pathway changes in the memory impairment of Alzheimer's disease. Ann Neurol 20: 472-481.

Hyman BT, Marzloff K, Arriagada PV. 1993. The lack of accumulation of senile plaques or amyloid burden in Alzheimer's disease suggests a balance between amyloid deposition and resolution. J Neuropathol Exp Neurol 52: 594-600.

Iacono D, O'Brien R, Resnick SM, Zonderman AB, Pletnikova O, Rudow G, An Y, West MJ, Crain B, Troncoso JC. 2008. Neuronal hypertrophy in asymptomatic Alzheimer disease. J Neuropathol Exp Neurol 67: 578-589.

Ikegami K, Kimura T, Katsuragi S, Ono T, Yamamoto H, Miyamoto E, Miyakawa T. 1996. Immunohistochemical examination of phophorylated tau in granulovacuolar degeneration granules. Psychiatry Clin Neurosci 50: 137-140.

Ingelsson $\mathrm{M}$, Fukumoto $\mathrm{H}$, Newell $\mathrm{KL}$, Growdon $\mathrm{JH}$, Hedley-Whyte ET, Frosch MP, Albert MS, Hyman BT, Irizarry MC. 2004. Early A $\beta$ accumulation and progressive synaptic loss, gliosis, and tangle formation in $\mathrm{AD}$ brain. Neurology 62: 925-931.

Iqbal K, Grundke-Iqbal I. 2002. Neurofibrillary pathology leads to synaptic loss and not the other way around in Alzheimer disease. J Alzheimers Dis 4: 235-238.
Itagaki S, McGeer PL, Akiyama H, Zhu S, Selkoe D. 1989. Relationship of microglia and astrocytes to amyloid deposits of Alzheimer disease. J Neuroimmunol 24: $173-182$.

Iwai A, Masliah E, Yoshimoto M, Ge N, Flanagan L, de Silva HA, Kittel A, Saitoh T. 1995. The precursor protein of non- $A \beta$ component of Alzheimer's disease amyloid is a presynaptic protein of the central nervous system. Neuron 14: $467-475$.

Jack CR Jr, Lowe VJ, Weigand SD, Wiste HJ, Senjem ML, Knopman DS, Shiung MM, Gunter JL, Boeve BF, Kemp BJ, et al. 2009. Serial PIB and MRI in normal, mild cognitive impairment and Alzheimer's disease: Implications for sequence of pathological events in Alzheimer's disease. Brain 132: 1355-1365.

Janvin CC, Larsen JP, Salmon DP, Galasko D, Hugdahl K, Aarsland D. 2006. Cognitive profiles of individual patients with Parkinson's disease and dementia: Comparison with dementia with Lewy bodies and Alzheimer's disease. Mov Disord 21: 337-342.

Jellinger KA, Attems J. 2006. Does striatal pathology distinguish Parkinson disease with dementia and dementia with Lewy bodies? Acta Neuropathol 112: 253-260.

Jicha GA, Parisi JE, Dickson DW, Johnson K, Cha R, Ivnik RJ, Tangalos EG, Boeve BF, Knopman DS, Braak H, et al. 2006. Neuropathologic outcome of mild cognitive impairment following progression to clinical dementia. Arch Neurol 63: 674-681.

Jin K, Peel AL, Mao XO, Xie L, Cottrell BA, Henshall DC Greenberg DA. 2004. Increased hippocampal neurogenesis in Alzheimer's disease. Proc Natl Acad Sci 101: 343-347.

Kahn J, Anderton BH, Probst A, Ulrich J, Esiri MM. 1985. Immunohistological study of granulovacuolar degeneration sing monoclonal antibodies to neurofilaments. $J$ Neurol Neurosurg Psychiatry 48: 924-926.

Kannanayakal TJ, Tao H, Vandre DD, Kuret J. 2006. Casein kinase-1 isoforms differentially associate with neurofibrillary and granulovauoclar degeneration lesions. Acta Neuropathol 111: 413-421.

Khachaturian ZS. 1985. Diagnosis of Alzheimer's disease. Arch Neurol 42: 1092-1105.

Kidd M. 1963. Paired helical filaments in electron microscopy of Alzheimer's disease. Nature 197: 192-193.

Kidd M. 1964. Alzheimer's disease: An electron microscopy study. Brain 87: 307-320.

Kimura T, Fukuda T, Sahara N, Yamashita S, Murayama M, Mirozoki T, Yoshiike Y, Lee B, Sotiropoulos I, Maeda S, et al. 2010. Aggregation of detergent-insoluble tau is involved in neuronal loss but not in synaptic loss. J Biol Chem 285: 38692-38699.

Klein WL. 2002. A $\beta$ toxicity in Alzheimer's disease: Globular oligomers (ADDLs) as new vaccine and drug targets. Neurochem Int 41: 345-352.

Klein WL, Krafft GA, Finch CE. 2001. Targeting small Aß oligomers: The solution to an Alzheimer's disease conundrum? Trends Neurosci 24: 219-224.

Klucken J, McLean PJ, Gomez-Tortosa E, Ingelsson M, Hyman BT. 2003. Neuritic alterations and neural system dysfunction in Alzheimer's disease and dementia with Lewy bodies. Neurochem Res 28: 1683-1691. 
Klyubin I, Betts V, Welzel AT, Blennow K, Zetterberg H, Wallin A, Lemere CA, Cullen WK, Peng Y, Wisniewski T, et al. 2008. Amyloid $\beta$ protein dimer-containing human CSF disrupts synaptic plasticity: Prevention by systemic passive immunization. J Neurosci 28: 42314237.

Knopman DS, Parisi JE, Salviati A, Floriach-Robert M, Boeve BF, Ivnik RJ, Smith GE, Dickson DW, Johnson KA, Petersen LE, et al. 2003. Neuropathology of cognitively normal elderly. J Neuropathol Exp Neurol 62: 1087-1095.

Knowles RB, Wyart C, Buldyrev SV, Cruz L, Urbanc B, Hasselmo ME, Stanley HE, Hyman BT. 1999. Plaque-induced neurite abnormalities: implications for disruption of neural networks in Alzheimer's disease. Proc Natl Acad Sci 96: 5274-5279.

Knudsen KA, Rosand J, Karluk D, Greenberg SM. 2001. Clinical diagnosis of cerebral amyloid angiopathy: Validation of the Boston criteria. Neurology 56: 537-539.

Koffie RM, Meyer-Luehmann M, Hashimoto T, Adams KW, Mielke ML, Garcia-Alloza M, Micheva KD, Smith SJ, Kim ML, Lee VM, et al. 2009. Oligomeric amyloid $\beta$ associates with postsynaptic densities and correlates with excitatory synapse loss near senile plaques. Proc Natl Acad Sci 106: 4012-4017.

Kramer ML, Schulz-Schaeffer WJ. 2007. Presynaptic $\alpha$-synuclein aggregates, not Lewy bodies, cause neurodegeneration in dementia with Lewy bodies. J Neurosci 27: 1405-1410.

Lacor PN, Buniel MC, Furlow PW, Clemente AS, Velasco PT, Wood M, Viola KL, Klein WL. 2007. A $\beta$ oligomerinduced aberrations in synapse composition, shape, and density provide a molecular basis for loss of connectivity in Alzheimer's disease. J Neurosci 27: 796-807.

LaFerla F, Tinkle B, Bieberich C, Haudenschild C, Jay G. 1995. The Alzheimer's A $\beta$ peptide induces neurodegeneration and apoptotic cell death in transgenic mice. Nat Genet 9: 21-30.

Lagalwar S, Berry RW, Binder LI. 2007. Regulation of hippocampal phospho-SAPK/JNK granules in Alzheimer's disease and tauopathies to granulovacuolar degeneration bodies. Acta Neuropathol 113: 63-73.

Lambert MP, Barlow AK, Chromy BA, Edwards C, Freed R, Liosatos M, Morgan TE, Rozovsky I, Trommer B, Viola KL, et al. 1998. Diffusible, nonfibrillar ligands derived from $A \beta 1-42$ are potent central nervous system neurotoxins. Proc Natl Acad Sci 95: 6448-6453.

Lashuel HA, Petre BM, Wall J, Simon M, Nowak RJ, Walz T, Lansbury PT Jr. 2002. $\alpha$-synuclein, especially the Parkinson's disease-associated mutants, forms pore-like annular and tubular protofibrils. J Mol Biol 322: 1089-1102.

Lee SC, Zhao ML, Hirano A, Dickson DW. 1999. Inducible nitric oxide synthase immunoreactivity in the Alzheimer disease hippocampus: Association with Hirano bodies, neurofibrillary tangles, and senile plaques. J Neuropathol Exp Neurol 58: 1163-1169.

Lee VM, Goedert M, Trojanowski JQ. 2001. Neurodegenerative tauopathies. Annu Rev Neurosci 24: 1121-1159.

Leroy K, Boutajangout A, Authelet M, Woodgett JR, Anderton BH, Brion JP. 2002. The active form of glycogen synthase kinase- $3 \beta$ is associated with granulovacuolar degeneration in neurons in Alzheimer's disease. Acta Neuropathol 103: 91-99.

Lesne S, Koh MT, Kotilinek L, Kayed R, Glabe CG, Yang A, Gallagher M, Ashe KH. 2006. A specific amyloid- $\beta$ protein assembly in the brain impairs memory. Nature 440: 352-357.

Leverenz JB, Fishel MA, Peskind ER, Montine TJ, Nochlin D, Steinbart E, Raskind MA, Schellenberg GD, Bird TD, Tsuang D. 2006. Lewy body pathology in familial Alzheimer disease: Evidence for disease- and mutation-specific pathologic phenotype. Arch Neurol 63: 370-376.

Li B, Yamamori H, Tatebayashi Y, Shafit-Zagardo B, Tanimukai H, Chen S, Iqbal K, Grundke-Iqbal I. 2008. Failure of neuronal maturation in Alzheimer disease dentate gyrus. J Neuropathol Exp Neurol 67: 78-84.

Lippa CF, Hamos JE, Pulaski-Salo D, DeGennaro LJ, Drachman DA. 1992. Alzheimer's disease and aging: Effects on perforant pathway perikarya and synapses. Neurobiol Aging 13: 405-411.

Lippa CF, Fujiwara H, Mann DM, Giasson B, Baba M, Schmidt ML, Nee LE, O'Connell B, Pollen DA, St GeorgeHyslop P, et al. 1998. Lewy bodies contain altered $\alpha$-synuclein in brains of many familial Alzheimer's disease patients with mutations in presenilin and amyloid precursor protein genes. Am J Pathol 153: 1365-1370.

Lippa CF, Schmidt ML, Lee VM, Trojanowski JQ. 1999. Antibodies to $\alpha$-synuclein detect Lewy bodies in many Down's syndrome brains with Alzheimer's disease. Ann Neurol 45: 353-357.

Lippa CF, Duda JE, Grossman M, Hurtig HI, Aarsland D, Boeve BF, Brooks DJ, Dickson DW, Dubois B, Emre M, et al. 2007. DLB and PDD boundary issues: Diagnosis, treatment, molecular pathology, and biomarkers. Neurology 68: 812-819.

Litvan I, MacIntyre A, Goetz CG, Wenning GK, Jellinger K, Verny M, Bartko JJ, Jankovic J, McKee A, Brandel JP, et al. 1998. Accuracy of the clinical diagnoses of Lewy body disease, Parkinson disease, and dementia with Lewy bodies: A clinicopathologic study. Arch Neurol 55: 969-978.

Lue LF, Brachova L, Civin WH, Rogers J. 1996. Inflammation, $A \beta$ deposition, and neurofibrillary tangle formation as correlates of Alzheimer's disease neurodegeneration. J Neuropathol Exp Neurol 55: 1083-1088.

Maciver SK, Harrington CR. 1995. Two actin binding proteins, actin depolymerizing factor and cofilin, are associated with Hirano bodies. Neuroreport 6: 1985-1988.

Mandal PK, Pettegrew JW, Masliah E, Hamilton RL, Mandal R. 2006. Interaction between $A \beta$ peptide and $\alpha$ synuclein: Molecular mechanisms in overlapping pathology of Alzheimer's and Parkinson's in dementia with Lewy body disease. Neurochem Res 31: 1153-1162.

Mandelkow EM, Mandelkow E. 1998. Tau in Alzheimer's disease. Trends Cell Biol 8: 425-427.

Markesbery WR, Schmitt FA, Kryscio RJ, Davis DG, Smith CD, Wekstein DR. 2006. Neuropathologic substrate of mild cognitive impairment. Arch Neurol 63: 38-46.

Masliah E. 2000. The role of synaptic proteins in Alzheimer's disease. Ann NY Acad Sci 924: 68-75.

Masliah E, Terry R. 1993. The role of synaptic proteins in the pathogenesis of disorders of the central nervous system. Brain Pathol 3: 77-85. 
Masliah E, Terry R. 1994. The role of synaptic pathology in the mechanisms of dementia in Alzheimer's disease. Clin Neurosci 1: 192-198.

Masliah E, Terry RD, Mallory M, Alford M, Hansen LA. 1990. Diffuse plaques do not accentuate synapse loss in Alzheimer's disease. Am J Pathol 137: 1293-1297.

Masliah E, Mallory M, Hansen L, Alford M, Albright T, Terry R, Shapiro P, Sundsmo M, Saitoh T. 1991. Immunoreactivity of CD45, a protein phosphotyrosine phosphatase, in Alzheimer disease. Acta Neuropathol 83: 12-20.

Masliah E, Mallory M, DeTeresa R, Alford M, Hansen L. 1993a. Differing patterns of aberrant neuronal sprouting in Alzheimer's disease with and without Lewy bodies. Brain Res 617: 258-266.

Masliah E, Mallory M, Hansen L, DeTeresa R, Terry RD. 1993b. Quantitative synaptic alterations in the human neocortex during normal aging. Neurology 43: 192-197.

Masliah E, Mallory M, Hansen L, DeTeresa R, Alford M, Terry R. 1994. Synaptic and neuritic alterations during the progression of Alzheimer's disease. Neurosci Lett 174: 67-72.

Masliah E, Mallory M, Alford M, DeTeresa R, Hansen LA, McKeel DW Jr, Morris JC. 2001a. Altered expression of synaptic proteins occurs early during progression of Alzheimer's disease. Neurology 56:127-129.

Masliah E, Rockenstein E, Veinbergs I, Sagara Y, Mallory M, Hashimoto M, Mucke L. 2001b. $\beta$-amyloid peptides enhance $\alpha$-synuclein accumulation and neuronal deficits in a transgenic mouse model linking Alzheimer's disease and Parkinson's disease. Proc Natl Acad Sci 98: 12245 12250.

Masliah E, Alford M, Adame A, Rockenstein E, Galasko D, Salmon D, Hansen LA, Thal LJ. 2003. A $\beta 1-42$ promotes cholinergic sprouting in patients with $\mathrm{AD}$ and Lewy body variant of AD. Neurology 61: 206-211.

McDonald JM, Savva GM, Brayne C, Welzel AT, Forster G, Shankar GM, Selkoe DJ, Ince PG, Walsh DM. 2010. The presence of sodium dodecyl sulphate-stable $A \beta$ dimers is strongly associated with Alzheimer-type dementia. Brain 133: 1328-1341.

McKeith IG. 2000. Spectrum of Parkinson's disease, Parkinson's dementia, and Lewy body dementia. Neurol Clin 18: 865-902.

McKeith IG. 2006. Consensus guidelines for the clinical and pathologic diagnosis of dementia with Lewy bodies (DLB): Report of the Consortium on DLB International Workshop. J Alzheimers Dis 9: 417-423.

McKeith IG, Galasko D, Kosaka K, Perry EK, Dickson DW, Hansen LA, Salmon DP, Lowe J, Mirra SS, Byrne EJ, et al. 1996. Consensus guidelines for the clinical and pathologic diagnosis of dementia with Lewy bodies (DLB): Report of the consortium on DLB international workshop. Neurology 47: 1113-1124.

McKeith IG, Dickson DW, Lowe J, Emre M, O’Brien JT, Feldman H, Cummings J, Duda JE, Lippa C, Perry EK, et al. 2005. Diagnosis and management of dementia with Lewy bodies: Third report of the DLB consortium. Neurology 65: $1863-1872$.

Mena R, Robitaille Y, Cuello AC. 1992. New patterns of intraneuronal accumulation of the microtubular binding domain of tau in granulovacuolar degeneration. J Geriatr Psychiatry Neurol 5: 132-141.
Mirra SS, Heyman A, McKeel D, Sumi SM, Crain BJ, Brownlee LM, Vogel FS, Hughes JP, van Belle G, Berg L. 1991. The Consortium to Establish a Registry for Alzheimer's Disease (CERAD). Part II. Standardization of the neuropathological assessment of Alzheimer's disease. Neurology 41: 479-486.

Mirra SS, Gearing M, Nash F. 1997. Neuropathological assessment of Alzheimer's disease. Neurology 49: S14S16.

Münch G, Cunningham AM, Riederer P, Braak E. 1998. Advance glycation endproducts are associated with Hirano bodies in Alzheimer's disease. Brain Res 796: 307-310.

Muñoz DG, Wang D, Greenberg BD. 1993. Hirano bodies accumulate $C$-terminal sequences of $\beta$-amyloid precursor protein ( $\beta$-APP) epitopes. J Neuropathol Exp Neurol 52: $14-21$.

Neuropathology Group of the Medical Research Council Cognitive Function and Aging Study (MRC CFAS). 2001. Pathological correlates of late-onset dementia in a multicenter community-based population in England and Wales. Lancet 357: 169-175.

Nixon RA, Cataldo AM. 2006. Lysosomal system pathways: Genes to neurodegeneration in Alzheimer's disease. J Alzheimers Dis 9: 277-289.

Okamoto K, Hirai S, Iizuka T, Yanagisawa T, Watanabe M. 1991. Reexamination of granulovacuolar degeneration. Acta Neuropathol 82: 340-345.

Olichney JM, Hansen LA, Hoffstetter CR, Lee JH, Katzman R, Thal LJ. 2000. Association between severe cerebral amyloid angiopathy and cerebrovascular lesions in $\mathrm{Alz}$ heimer disease is not a spurious one attributable to apolipoprotein E4. Arch Neurol 57: 869-874.

Palop JJ, Jones B, Kekonius L, Chin J, Yu GQ, Raber J, Masliah E, Mucke L. 2003. Neuronal depletion of calciumdependent proteins in the dentate gyrus is tightly linked to Alzheimer's disease-related cognitive deficits. Proc Natl Acad Sci 100: 9572-9577.

Palop JJ, Mucke L, Roberson ED. 2011. Quantifying biomarkers of cognitive dysfunction and neuronal network hyperexcitability in mouse models of Alzheimer's disease: Depletion of calcium-dependent proteins and inhibitory hippocampal remodeling. Methods Mol Biol 670: $245-262$.

Pérez-Gracia E, Torrejón-Escribano B, Ferrer I. 2008. Dystrophic neurites of senile plaques in Alzheimer's disease are deficient in cytochrome c oxidase. Acta Neuropathol 116: $261-268$.

Perlson E, Maday S, Fu MM, Moughamian AJ, Holzbaur EL. 2010. Retrograde axonal transport: Pathways to cell death? Trends Neurosci 33: 335-344

Perry EK, Tomlinson BE, Blessed G, Bergmann K, Gibson PH, Perry RH. 1978. Correlation of cholinergic abnormalities with senile plaques and mental test scores in senile dementia. Br Med J 2: 1457-1459.

Petersen RC. 2004. Mild cognitive impairment as a diagnostic entity. J Intern Med 256: 183-194.

Petersen RC, Smith GE, Waring SC, Ivnik RJ, Tangalos EG, Kokmen E. 1999. Mild cognitive impairment: Clinical characterization and outcome. Arch Neurol 56: 303-308. 
Petersen RC, Doody R, Kurz A, Mohs RC, Morris JC, Rabins PV, Ritchie K, Rossor M, Thal L, Winblad B. 2001. Current concepts in mild cognitive impairment. Arch Neurol 58: 1985-1992

Petersen RC, Parisi JE, Dickson DW, Johnson KA, Knopman DS, Boeve BF, Jicha GA, Ivnik RJ, Smith GE, Tangalos EG, et al. 2006. Neuropathologic features of amnestic mild cognitive impairment. Arch Neurol 63: 665-672.

Pfeifer LA, White LR, Ross GW, Petrovich H, Launer LJ. 2002. Cerebral amyloid angiopathy and cognitive function: The HAAS autopsy study. Neurology 58: 1629 1634.

Pham E, Crews L, Ubhi K, Hansen L, Adame A, Cartier A, Salmon D, Galasko D, Michael S, Savas JN, et al. 2010 Progressive accumulation of amyloid- $\beta$ oligomers in Alzheimer's disease and in amyloid precursor protein transgenic mice is accompanied by selective alterations in synaptic scaffold proteins. FEBS J 277: 3051-3067.

Pike CJ, Cummings BJ, Cotman CW. 1995. Early association of reactive astrocytes with senile plaques in Alzheimer's disease. Exp Neurol 132: 172-179.

Pletnikova O, West N, Lee MK, Rudow GL, Skolasky RL, Dawson TM, Marsh L, Troncoso JC. 2005. A $\beta$ deposition is associated with enhanced cortical $\alpha$-synuclein lesions in Lewy body diseases. Neurobiol Aging 26: 1183-1192.

Price DL, Altschuler RJ, Struble RG, Casanova MF, Cork LC Murphy DB. 1986. Sequestration of tubulin in neurons in Alzheimer's disease. Brain Res 385: 305-310.

Price JL, Ko AI, Wade MJ, Tsou SK, McKeel DW, Morris JC. 2001. Neuron number in the entorhinal cortex and CA1 in preclinical Alzheimer disease. Arch Neurol 58: 1395-1402.

Price JL, McKeel DW Jr, Buckles VD, Roe CM, Xiong C, Grundman M, Hansen LA, Petersen RC, Parisi JE, Dickson DW, et al. 2009. Neuropathology of nondemented aging: Presumptive evidence for preclinical Alzheimer disease. Neurobiol Aging 30: 1026-1036.

Riudavets MA, Iacono D, Resnick SM, O’Brien R, Zonderman AB, Martin LJ, Rudow G, Pletnikova O, Troncoso JC. 2007. Resistance to Alzheimer's pathology is associated with nuclear hypertrophy in neurons. Neurobio Aging 28: 1484-1492.

Rockenstein E, Schwach G, Ingolic E, Adame A, Crews L, Mante M, Pfragner R, Schreiner E, Windisch M, Masliah E. 2005. Lysosomal pathology associated with alpha-synuclein accumulation in transgenic models using an eGFP fusion protein. J Neurosci Res 80: 247-259.

Rogers J, Luber-Narod J, Styren S, Civin W. 1988. Expression of immune system-associated antigens by cells of the human central nervous system: Relationship to the pathology of Alzheimer's disease. Neurobiol Aging 9: 339-349.

Rosenberg RN. 2005. New presenilin 1 mutation with Alzheimer disease and Lewy bodies. Arch Neurol 62: 1808.

Rossiter JP, Anderson LL, Yang F, Cole GM. 2000. Caspasecleaved actin (fractin) immunolabeling of Hirano bodies. Neuropathol Appl Neurobiol 26: 342-346.

Scheff SW, Price DA. 1993. Synapse loss in the temporal lobe in Alzheimer's disease. Ann Neurol 33: 190-199.

Scheff SW, DeKosky ST, Price DA. 1990. Quantitative assessment of cortical synaptic density in Alzheimer's disease. Neurobiol Aging 11: 29-37.
Scheff SW, Price DA, Schmitt FA, Mufson EJ. 2006. Hippocampal synaptic loss in early Alzheimer's disease and mild cognitive impairment. Neurobiol Aging 27: 13721384.

Scheff SW, Price DA, Schmitt FA, DeKosky ST, Mufson EJ. 2007. Synaptic alterations in CA1 in mild Alzheimer disease and mild cognitive impairment. Neurology 68: $1501-1508$.

Schmidt ML, Lee VM, Trojanowski JQ. 1989. Analyses of epitopes shared by Hirano bodies and neurofilament proteins in normal and Alzheimer's disease hippocampus. Lab Invest 60: 513-522.

Schmitt FA, Davis DG, Wekstein DR, Smith CD, Ashford JW, Markesbery WR. 2000. "Preclinical" AD revisited. Neuropathology of cognitively normal older adults. Neurology 55: 370-376.

Schneider JA, Arvanitakis Z, Bang W, Bennet DA. 2007. Mixed brain pathologies account for most dementia cases in community-dwelling older persons. Neurology 69: 2197-2204.

Schneider JA, Arvanitakis Z, Leurgans SE, Bennet DA. 2009. The neuropathology of probable Alzheimer's disease and mild cognitive impairment. Ann Neurol 66: 200-208.

Scott DA, Tabarean I, Tang Y, Cartier A, Masliah E, Roy S. 2010. A pathologic cascade leading to synaptic dysfunction in $\alpha$-synuclein-induced neurodegeneration. $\mathrm{J} \mathrm{Neu-}$ rosci 30: 8083-8095.

Selkoe D. 1989. Amyloid $\beta$ protein precursor and the pathogenesis of Alzheimer's disease. Cell 58: 611-612.

Selkoe D. 1990. Amyloid $\beta$-protein deposition as a seminal pathogenic event in AD: An hypothesis. Neurobiol Aging 11: 299.

Selkoe D. 1993. Physiological production of the $\beta$-amyloid protein and the mechanisms of Alzheimer's disease. Trends Neurosci 16: 403-409.

Selkoe DJ. 2008. Soluble oligomers of the amyloid $\beta$-protein impair synaptic plasticity and behavior. Behav Brain Res 192: $106-113$.

Selznick LA, Holtzman DM, Han BH, Gökden M, Srinivasan AN, Johnson EM Jr, Roth KA. 1999. In situ immunodetection of neuronal caspase-3 activation in Alzheimer disease. J Neuropathol Exp Neurol 58: 1020-1026.

Serrano-Pozo A, Mielke ML, Gómez-Isla E, Betensky RA, Growdon JH, Frosch MP, Hyman BT. 2011. Reactive glia not only associates with plaques but also parallels tangles in Alzheimer's disease. Am J Pathol 179. doi: 10.1016/j.ajpath.2011.05.047.

Shankar GM, Li S, Mehta TH, García-Munoz A, Shepardson NE, Smith I, Brett FM, Farrell MA, Rowan MJ, Lemere CA, et al. 2008. Amyloid-beta protein dimers isolated directly from Alzheimer's brains impair synaptic plasticity and memory. Nat Med 14: 837-842.

Sisodia SS, Price DL. 1995 . Role of the $\beta$-amyloid protein in Alzheimer's disease. FASEB J 9: 366-370.

Skovronsky DM, Doms RW, Lee VM-Y. 1998. Detection of a novel intraneuronal pool of insoluble amyloid $\beta$-protein that accumulates with time in culture. J Cell Biol 141: 1031-1039.

Smith MA, Perry G, Richey PL, Sayre LM, Anderson VE, Beal MF, Kowall N. 1996. Oxidative damage in Alzheimer's. Nature 382: 120-121. 
A. Serrano-Pozo et al.

Snider BJ, Norton J, Coats MA, Chakraverty S, Hou CE, Jervis R, Lendon CL, Goate AM, McKeel DW Jr, Morris JC. 2005. Novel presenilin 1 mutation (S170F) causing Alzheimer disease with Lewy bodies in the third decade of life. Arch Neurol 62: 1821-1830.

Spillantini M, Schmidt M, Lee V-Y, Trojanowski J, Jakes R, Goedert M. 1997. $\alpha$-Synuclein in Lewy bodies. Nature 388: $839-840$.

Spires-Jones TL, de Calignon A, Matsui T, Zehr C, Pitstick R, Wu HY, Osetek JD, Jones PB, Bacskai BJ, Feany MB et al. 2007. In vivo imaging reveals dissociation between caspase activation and acute neuronal death in tanglebearing neurons. J Neurosci 28: 862-867.

Stadelmann C, Deckwerth TL, Srinivasan A, Bancher C, Brück W, Jellinger K, Lassmann H. 1999. Activation of caspase-3 in single neurons and autophagic vacuoles of granulovacuolar degeneration in Alzheimer's disease. Evidence for apoptotic cell death. Am J Pathol 155: 1459-1466.

Su JH, Cummings BJ, Cotman CW. 1993. Identification and distribution of axonal dystrophic neurites in Alzheimer's disease. Brain Res 625: 228-237.

$\mathrm{Su}$ JH, Cummings BJ, Cotman CW. 1994. Subpopulations of dystrophic neuritis in Alzheimer's brain with distinct immunocytochemical and argentophilic characteristics. Brain Res 637: 37-44.

Su JH, Cummings BJ, Cotman CW. 1996. Plaque biogenesis in brain aging and Alzheimer's disease. I. Progressive changes in phosphorylation states of paired helical filaments and neurofilaments. Brain Res 739: 79-87.

Su JH, Cummings BJ, Cotman CW. 1998. Plaque biogenesis in brain aging and Alzheimer's disease. II. Progressive transformation and developmental sequence of dystrophic neurites. Acta Neuropathol 96: 463-471.

Su JH, Zhao M, Anderson AJ, Srinivasan A, Cotman CW. 2001. Activated-caspase-3 expression in Alzheimer's and aged control brain: Correlation with Alzheimer pathology. Brain Res 898: 350-357.

Su JH, Kesslak JP, Head E, Cotman CW. 2002. Caspasecleaved amyloid precursor protein and activated caspase- 3 are co-localized in the granules of granulovacuolar degeneration in Alzheimer's disease and Down's syndrome brain. Acta Neuropathol 104: 1-6.

Takeda A, Mallory M, Sundsmo M, Honer W, Hansen L, Masliah E. 1998. Abnormal accumulation of NACP/ $\alpha$-synuclein in neurodegenerative disorders. Am J Pathol 152: $367-372$.

Teipel SJ, Flatz WH, Heinsen H, Bokde AL, Schoenberg SO, Stockel S, Dietrich O, Reiser MF, Moller HJ, Hampel H. 2005. Measurement of basal forebrain atrophy in Alzheimer's disease using MRI. Brain 128: 2626-2644.

Terry R, Peck A, DeTeresa R, Schechter R, Horoupian D. 1981. Some morphometric aspects of the brain in senile dementia of the Alzheimer type. Ann Neurol 10: $184-192$.

Terry RD, Masliah E, Salmon DP, Butters N, DeTeresa R, Hill R, Hansen LA, Katzman R. 1991. Physical basis of cognitive alterations in Alzheimer's disease: Synapse loss is the major correlate of cognitive impairment. Ann Neurol 30: $572-580$.

Terry R, Hansen L, Masliah E. 1994. Structural basis of the cognitive alterations in Alzheimer disease. In Alzheimer disease (ed. R. Terry, R. Katzman), pp. 179-196. Raven, New York.

Thakur A, Wang X, Siedlak SL, Perry G, Smith MA, Zhu X. 2007. c-Jun phosphorylation in Alzheimer disease. J Neurosci Res 85: $1668-1673$.

Thal DR, Rüb U, Orantes M, Braak H. 2002. Phases of $\mathrm{A} \beta$-deposition in the human brain and its relevance for the development of AD. Neurology 58: 1791-1800.

The National Institute of Aging, and Reagan Institute working group on the diagnostic criteria for the neuropathological assessment of Alzheimer's disease. 1997. Consensus recommendations for the postmortem diagnosis of Alzheimer's disease. Neurobiol Aging 18: S1-S2.

Townsend M, Shankar GM, Mehta T, Walsh DM, Selkoe DJ. 2006. Effects of secreted oligomers of amyloid $\beta$-protein on hippocampal synaptic plasticity: A potent role for trimers. J Physiol 572: 477-492.

Trojanowski JQ, Lee VM. 1998. Aggregation of neurofilament and $\alpha$-synuclein proteins in Lewy bodies: Implications for the pathogenesis of Parkinson disease and Lewy body dementia. Arch Neurol 55: 151-152.

Trojanowski JQ, Lee VM. 2000. "Fatal attractions" of proteins. A comprehensive hypothetical mechanism underlying Alzheimer's disease and other neurodegenerative disorders. Ann NY Acad Sci 924: 62-67.

Trojanowski JQ, Goedert M, Iwatsubo T, Lee VM. 1998. Fatal attractions: Abnormal protein aggregation and neuron death in Parkinson's disease and Lewy body dementia. Cell Death Differ 5: 832-837.

Troncoso JC, Sukhov RR, Kawas CH, Koliatsos VE. 1996. In situ labeling of dying cortical neurons in normal aging and in Alzheimer's disease: Correlations with senile plaques and disease progression. J Neuropathol Exp Neurol 55: 1134-1142.

Tsigelny IF, Bar-On P, Sharikov Y, Crews L, Hashimoto M, Miller MA, Keller SH, Platoshyn O, Yuan JX, Masliah E. 2007. Dynamics of $\alpha$-synuclein aggregation and inhibition of pore-like oligomer development by $\beta$-synuclein. FEBS J 274: 1862-1877.

Tsigelny IF, Crews L, Desplats P, Shaked GM, Sharikov Y, Mizuno H, Spencer B, Rockenstein E, Trejo M, Platoshyn O, et al. 2008. Mechanisms of hybrid oligomer formation in the pathogenesis of combined Alzheimer's and Parkinson's diseases. PLoS One 3: e3135.

Tsuboi Y, Dickson DW. 2005. Dementia with Lewy bodies and Parkinson's disease with dementia: Are they different? Parkinsonism Relat Disord 11: S47-S51.

Uboga NV, Price JL. 2000. Formation of diffuse and fibrillar tangles in aging and early Alzheimer's disease. Neurobiol Aging 21: 1-10.

Urbanc B, Cruz L, Le R, Sanders J, Hsiao-Ashe K, Stanley HE, Irizarry MC, Hyman BT. 2002. Neurotoxic effects of thioflavin S-positive amyloid deposits in transgenic mice and Alzheimer's disease. Proc Natl Acad Sci 99: 13990-13995.

Vehmas AK, Kawas CH, Stewart WF, Troncoso JC. 2003. Immune reactive cells in senile plaques and cognitive decline in Alzheimer's disease. Neurobiol Aging 24: $321-331$. 
Neuropathological Alterations in Alzheimer Disease

Wakabayashi K, Matsumoto K, Takayama K, Yoshimoto M Takahashi H. 1997. NACP, a presynaptic protein, immunoreactivity in Lewy bodies in Parkinson's disease. Neurosci Lett 239: 45-48.

Walsh DM, Selkoe DJ. 2004. Oligomers on the brain: The emerging role of soluble protein aggregates in neurodegeneration. Protein Pept Lett 11: 213-228.

Walsh DM, Klyubin I, Fadeeva JV, Cullen WK, Anwyl R, Wolfe MS, Rowan MJ, Selkoe DJ. 2002. Naturally secreted oligomers of amyloid $\beta$ protein potently inhibit hippocampal long-term potentiation in vivo. Nature 416: $535-539$.

Weaver CL, Espinoza M, Kress Y, Davies P. 2000. Conformational change as one of the earliest alterations of tau in Alzheimer's disease. Neurobiol Aging 21: 719-727.

Wegmann S, Jung YJ, Chinnathambi S, Mandelkow EM, Mandelkow E, Muller DJ. 2010. Human tau isoforms assemble into ribbon-like fibrils that display polymorphic structure and stability. J Biol Chem 285: 2730227313.

West MJ, Kawas CH, Stewart WF, Rudow GL, Troncoso JC. 2004. Hippocampal neurons in pre-clinical Alzheimer's disease. Neurobiol Aging 25: 1205-1212.

Wisniewski HM, Narang HK, Terry RD. 1976. Neurofibrillary tangles of paired helical filaments. J Neurol Sci 27: $173-181$.
Woodhouse A, Vickers JC, Dickson TC. 2006a. Cytoplasmic cytochrome c immunolabeling in dystrophic neurites in Alzheimer's disease. Acta Neuropathol 112: 429-437.

Woodhouse A, Dickson TC, West AK, McLean CA, Vickers JC. 2006b. No difference in expression of apoptosisrelated proteins and apoptotic morphology in control, pathologically aged and Alzheimer's disease cases. Neurobiol Dis 22: 323-333.

Xu M, Shibayama H, Kobayashi H, Yamada K, Ishihara R, Zhao P, Takeuchi T, Yoshida K, Inagaki T, Nokura K. 1992. Granulovacuolar degeneration in the hippocampal cortex of aging and demented patients: A quantitative study. Acta Neuropathol 85: 1-9.

Yamazaki Y, Takahashi T, Hiji M, Kurashige T, Izumi Y, Yamawaki T, Matsumoto M. 2010. Immunopositivity for ESCRT-III subunit CHMP2B in granulovacuolar degeneration of neurons in the Alzheimer's disease hippocampus. Neurosci Lett 477: 86-90.

Yoshiyama Y, Higucho M, Zhang B, Huang SM, Iwata N, Saido TC, Maeda J, Suhara T, Trojanowski JQ, Lee VM. 2007. Synapse loss and microglial activation precede tangles in a P301S tauopathy mouse model. J Neuron 53: 337-351.

Zhu X, Raina AK, Rottkamp CA, Aliev G, Perry G, Boux H, Smith MA. 2001. Activation and redistribution of c-jun $\mathrm{N}$-terminal kinase/stress activated protein kinase in degenerating neurons in Alzheimer's disease. J Neurochem 76: 435-441. 


\section{$\&_{\mathrm{CSH}}^{\infty} \&$ Cold Spring Harbor

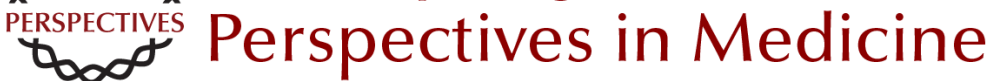

\section{Neuropathological Alterations in Alzheimer Disease}

Alberto Serrano-Pozo, Matthew P. Frosch, Eliezer Masliah and Bradley T. Hyman

Cold Spring Harb Perspect Med 2011; doi: 10.1101/cshperspect.a006189

Subject Collection The Biology of Alzheimer Disease

Animal Models of Alzheimer Disease

Frank M. LaFerla and Kim N. Green

Neurovascular Dysfunction and Faulty Amyloid $\beta$

-Peptide Clearance in Alzheimer Disease Abhay P. Sagare, Robert D. Bell and Berislav V. Zlokovic

Treatment Strategies Targeting Amyloid $\beta$-Protein Dale Schenk, Guriqbal S. Basi and Menelas N. Pangalos

The Ubiquitin-Proteasome System and the Autophagic-Lysosomal System in Alzheimer

Disease

Yasuo Ihara, Maho Morishima-Kawashima and Ralph Nixon

Neurotoxicity of Amyloid $\beta$-Protein: Synaptic and Network Dysfunction

Lennart Mucke and Dennis J. Selkoe

Proteolytic Degradation of Amyloid $\beta$-Protein Takaomi Saido and Malcolm A. Leissring

Brain Imaging in Alzheimer Disease

Keith A. Johnson, Nick C. Fox, Reisa A. Sperling, et al.

Symptomatic and Nonamyloid/Tau Based Pharmacologic Treatment for Alzheimer Disease Paul S. Aisen, Jeffrey Cummings and Lon S. Schneider
Alzheimer Disease in 2020

David M. Holtzman, Eckhard Mandelkow and Dennis J. Selkoe

The Genetics of Alzheimer Disease Rudolph E. Tanzi

Fluid Biomarkers in Alzheimer Disease

Kaj Blennow, Henrik Zetterberg and Anne M. Fagan

Epidemiology of Alzheimer Disease

Richard Mayeux and Yaakov Stern

Biochemistry and Cell Biology of Tau Protein in Neurofibrillary Degeneration

Eva-Maria Mandelkow and Eckhard Mandelkow

Biochemistry of Amyloid $\beta$-Protein and Amyloid

Deposits in Alzheimer Disease Colin L. Masters and Dennis J. Selkoe

The Neuropsychological Profile of Alzheimer

Disease

Sandra Weintraub, Alissa H. Wicklund and David P. Salmon

Apolipoprotein E and Apolipoprotein E Receptors: Normal Biology and Roles in Alzheimer Disease David M. Holtzman, Joachim Herz and Guojun Bu

For additional articles in this collection, see http://perspectivesinmedicine.cshlp.org/cgi/collection/ 